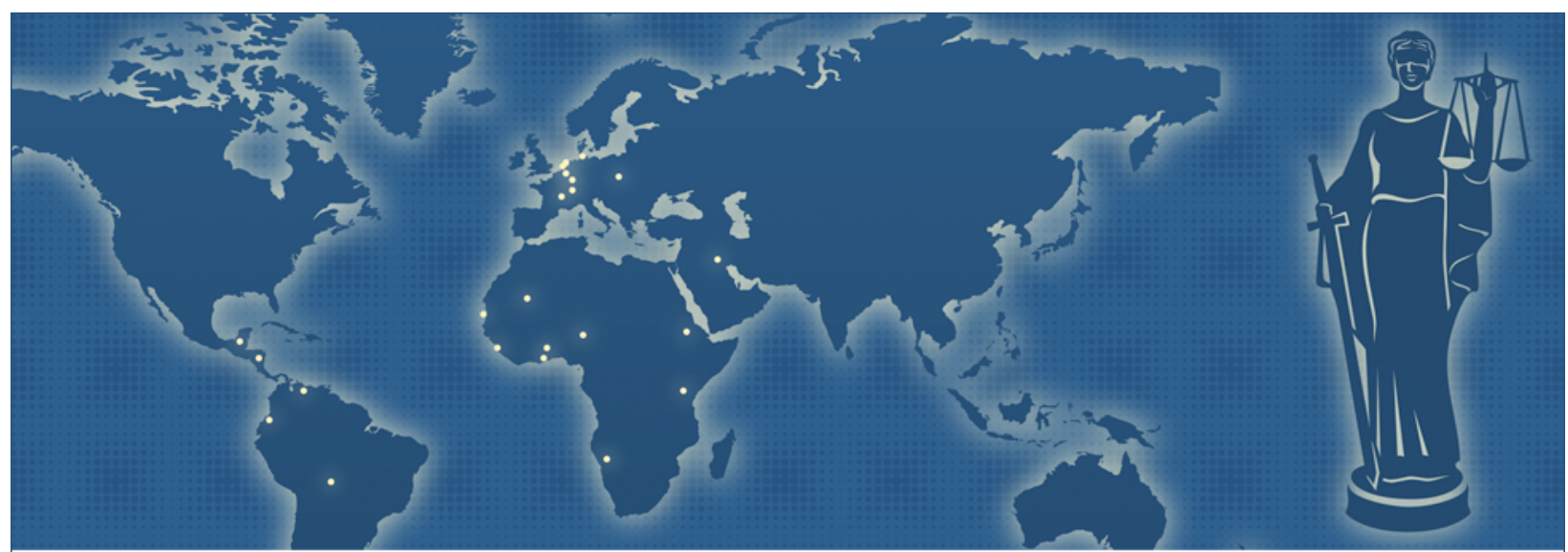

iCourts - The Danish National Research Foundation's Centre of Excellence for International Courts

iCourts Working Paper Series, No. 83, 2017

\title{
Opposing International Justice: Kenya's Integrated Backlash Strategy Against the ICC
}

\section{Laurence R. Helfer and Anne E. Showalter}

iCourts - The Danish National Research Foundation's

Centre of Excellence for International Courts

International Criminal Law Review, vol. 17 (2017, Forthcoming) 


\begin{abstract}
:
The government of Kenya has employed a wide range of strategies to undermine the recentlydismissed prosecutions of President Uhuru Kenyatta and Deputy President William Ruto before the International Criminal Court (ICC). This Article argues that these strategies are part of an integrated backlash campaign against the ICC, one that encompasses seemingly unrelated actions in multiple global, regional and national venues. We identify three overarching themes that connect these diverse measures - politicizing complementarity, regionalizing political opposition, and pairing instances of cooperation and condemnation to diffuse accusations of impunity. By linking its discrete acts of opposition to these three themes, the government ultimately increased the effectiveness of its campaign against the Court. Our findings provide new evidence to analyze others instances of backlash against international courts and institutions.
\end{abstract}

KEYWORDS: International Criminal Court, ICC, criminal justice, atrocities, Africa, backlash, postcolonialism, Kenya, African Union.

Laurence R. Helfer is Harry R. Chadwick, Sr. Professor of Law at Duke University School of Law, USA, and Permanent Visiting Professor at the Centre of Excellence for International Courts (iCourts), University of Copenhagen, Denmark.

E-mail: helfer@law.duke.edu

Anne E. Showalter is J.D. / LLM in International and Comparative Law at Duke University School of Law, USA.

E-mail: aes75@duke.edu 
This research is funded by the Danish National Research Foundation Grant no. DNRF105.

iCourts - Centre of Excellence for International Courts - focuses on the ever-growing role of international courts, their place in a globalizing legal order, and their impact on politics and society at large. To understand these crucial and contemporary interplays of law, politics, and society, iCourts hosts a set of deeply integrated interdisciplinary research projects on the causes and consequences of the proliferation of international courts.

iCourts opened in March 2012. The centre is funded by a large grant from the Danish National Research Foundation (for the period 2012-18). 


\section{Table of Contents}

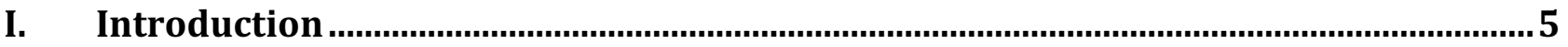

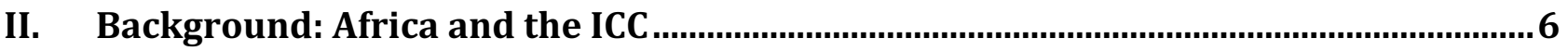

III. Overview of the ICC Prosecutions of Kenyatta and Ruto ........................................... 7

IV. Identifying Different Instances of Backlash against the ICC .................................... 11

A. Lobbying the U.N. Security Council to Defer or Terminate the ICC Prosecutions ............... 11

B. Motions by the Kenyan Parliament to Withdraw from the Rome Statute ...........................18

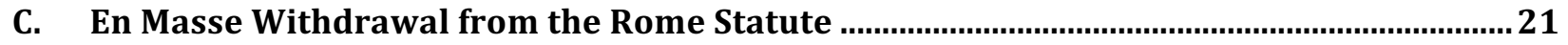

D. Attempts to Prosecute International Crimes Before Domestic Courts....................................23

E. Proposals to Prosecute International Crimes Before Regional Courts ............................... 27

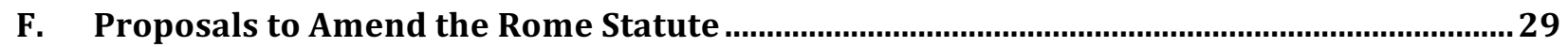

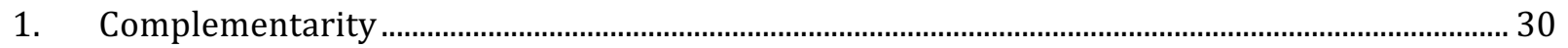

2. Administration of Justice and Independent Oversight Mechanism ............................................. 30

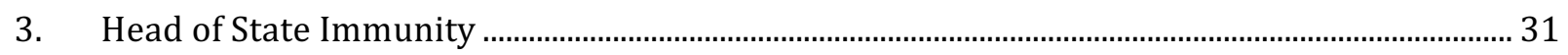

G. Lobbying to Avoid Requiring the Accused's Presence at Trial ................................................ 32

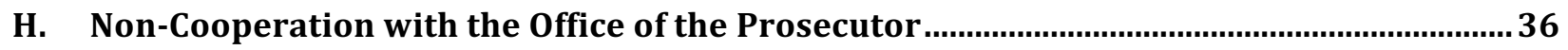

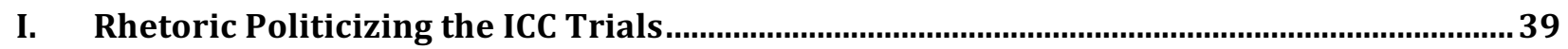

V. Three Overarching Themes of the Kenyan Backlash against the ICC ......................40

A. Cloaking Sovereignty Claims in Arguments about Complementarity ................................41

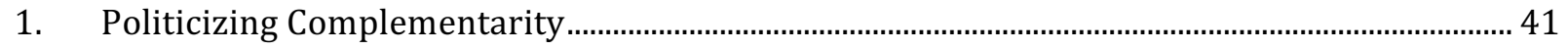

2. Eliding Positive and Negative Complementarity …………................................................................ 42

3. Raising Complementarity Arguments Without a Basis in International Law ............................. 44

B. Regionalizing Backlash: Making the Prosecutions a Pan-African Concern.......................... 45

1. Involving the African Union in Lobbying the Security Council for a Deferral ............................. 45

2. Raising En Masse Withdrawal Before the African Union .................................................................. 46

C. Coupling Condemnation with Cooperation to Diffuse Accusations of Impunity ……….......47

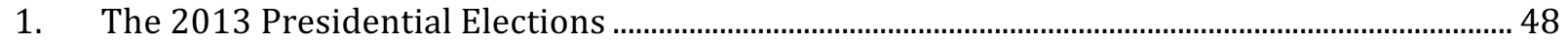

2. Kenyatta's Appearance in the Hague in October 2014 …….............................................................. 49

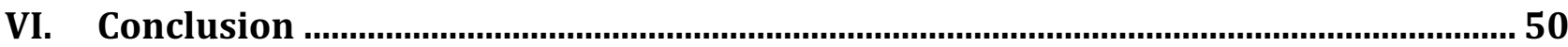




\section{Introduction}

Over the last several years, the government of Kenya has employed a wide range of strategies to undermine the prosecutions of President Uhuru Kenyatta ("Kenyatta") and Deputy President William Ruto ("Ruto") before the International Criminal Court ("ICC" or "the Court"). In 2011, Kenyatta and Ruto were charged with crimes against humanity for inciting widespread violence in the country following the presidential election held on December $27,2007 .{ }^{1}$ The government of Kenya responded by challenging the cases and attacking the Court. These efforts significantly_and ultimately successfully — undermined both prosecutions. The case against Kenyatta was dismissed in December 2014 on what the ICC Prosecutor called "a dark day for international criminal justice."2 Ruto's prosecution was dismissed on April 5, $2016^{3}$

This Article reviews and analyzes Kenya's concerted and unprecedented backlash against the ICC. We identify the diverse measures taken by the government in multiple venues to oppose the ICC prosecutions and explain how they amount to an integrated backlash strategy against the Court and its Prosecutor. Part II provides relevant background, briefly discussing the tensions surrounding the ICC's work in Africa before the Kenyatta and Ruto prosecutions began. Part III places the prosecutions in context, summarizing the post-election violence and the charges against each defendant relating to that violence. Part IV — the heart of the article — describes the different actions by which the Kenyan government opposed the ICC prosecutions. Part V highlights three overarching themes of Kenya's an integrated backlash strategy against the ICC. A brief conclusion identifies the implications of this Article's findings for future research on backlashes against other international

\footnotetext{
${ }_{1}^{1}$ See International Criminal Court: Situation in the Republic of Kenya, https://www.icc-cpi.int/kenya? $\ln =\mathrm{en}$.

${ }^{2}$ Statement of the Prosecutor of the International Criminal Court, Fatou Bensouda, on the Withdrawal of Charges Against Mr. Uhuru Muigai Kenyatta (Dec. 5, 2014), https://www.icc-cpi.int/Pages/item.aspx?name=Adjourn-Kenyatta05-12-2014.

${ }^{3}$ Prosecutor v. William Samoei Ruto and Joshua Arap Sang, Decision on Defence Applications for Judgments of Acquittal, ICC-01/09-01/11 (April 5, 2016), https://www.icc-cpi.int/CourtRecords/CR2016 02617.pdf.
} 
courts and tribunals. Part VI briefly concludes, identifying the implications of our findings for future research on backlashes against international courts and other international institutions.

\section{Background: Africa and the ICC}

Following the 1994 Rwandan genocide, many African governments saw the need for a permanent international criminal justice regime to confront mass human rights violations on the continent and protect weaker nations. ${ }^{4}$ In 1998, the Rome Statute of the International Criminal Court was adopted at a diplomatic conference sponsored by the United Nations ("UN"), ${ }^{5}$ leading, in 2002, to the creation of the first permanent international criminal tribunal. The ICC is tasked with investigating and prosecuting crimes against humanity, genocide, and war crimes that occur on the territory of a State party, that are committed by the national of a State Party, or that are referred to the Court by the UN Security Council ("UNSC" or "the Security Council").

African nations comprise the largest regional group of countries in the ICC Assembly of States Parties ("ASP"). ${ }^{6}$ However, the prosecution of President Omar al-Bashir of Sudan for international crimes committed in the Darfur region of that country proved to be a turning point in African governments' support for the ICC. ${ }^{7}$ The Security Council referred the situation in Darfur to the ICC in March 2005. After the Prosecutor applied for a warrant for al-Bashir's arrest on July $14,2008,{ }^{8}$ the African Union Peace and Security Council ("AU PSC") requested a one-year deferral of the

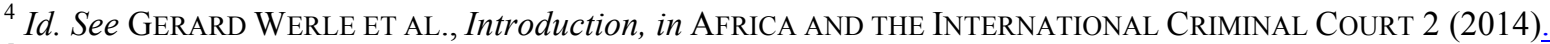

${ }^{5}$ John M. Mbaku, International Justice: The International Criminal Court and Africa, BROOKINGS INSTITUTE: AfRICAN Growth INITIATIVE (Dec. 2013), http://goo.gl/Y4FNXt.

${ }^{6}$ Tim Murithi, Policy Brief No. 8: The African Union and the International Criminal Court: An Embattled Relationship?, INSTITUTE FOR JUSTICE AND RECONCILIATION at 1(Mar. 2013), http://goo.gl/qs7gFt. Of the 134 States Parties to the Rome Statute, 34 are African States. United Nations Treaty Collection, https://treaties.un.org/Pages/ViewDetails.aspx?src=TREATY\&mtdsg_no=XVIII-10\&chapter=18\&lang=en. (last visited May 19, 2016).

${ }^{7}$ Id. See generally Kurt Mills, Bashir is Dividing Us: Africa and the International Criminal Court, 34 HuM. RTS. Q. 404 (2012).

${ }^{8}$ Case Information Sheet: The Prosecutor v. Omar Hassan Ahmad Al Bashir, InTERnational CRiminal Court (Mar. 26, 2015), https://www.icc-cpi.int/darfur/albashir/Documents/AlBashirEng.pdf.
} 
investigation by the UNSC — a procedure permitted by the Rome Statute. ${ }^{9}$ However, on March 4, 2009 , the ICC issued an arrest warrant for al-Bashir for war crimes and crimes against humanity. ${ }^{10}$ The next day, the AU PSC issued a second communique requesting deferral. ${ }^{11}$ The UNSC's failure to respond positively or negatively to these requests aroused a feeling of disrespect among African political leaders. $^{12}$

Expressing regret that the UNSC failed to defer the cases, the African Union ("AU”) formally decided, in July 2009, not to cooperate with the ICC in facilitating al-Bashir's arrest. ${ }^{13}$ Accusations that the Office of the Prosecutor was targeting Africa began in earnest around this time. ${ }^{14}$ Critics pointed to the fact that all ongoing ICC prosecutions were focused on Africa, despite the fact that African governments had referred several of these cases to the Court. These tensions underlie Kenya's subsequent backlash against the ICC in response to the Kenyatta and Ruto prosecutions.

\section{Overview of the ICC Prosecutions of Kenyatta and Ruto}

Ethnic tensions and violence have been linked to elections in Kenya since the country's independence, in part due to the congruence of tribal and electoral boundaries. ${ }^{15}$ After Mwai Kimbaki of the Party of National Unity ("PNU”) was declared the winner of the election held on December 27, 2007, supporters of his Orange Democratic Movement (“ODM”) opponent, Raila Odinga, alleged electoral fraud. Tribal violence between the candidates' constituencies erupted, including murder, rape, deportation, and forcible transfer of populations. The violence, which lasted three months,

\footnotetext{
${ }^{9}$ AU Peace and Security Council [AUPSC], Communique of the 142nd Meeting of the Peace and Security Council, PSC/MIN/Comm.(CXLII) (July 21, 2008), http://goo.gl/3U85j3.

${ }^{10}$ Prosecutor v. Al Bashir, Case No. ICC-02/05-01/09, Warrant of Arrest for Omar Hassan Ahmad Al Bashir, (Mar. 4, 2009), http://www.icc-cpi.int/iccdocs/doc/doc639078.pdf.

${ }^{11}$ AUPSC, Communique of the 175th Meeting of the Peace and Security Council, PSC/PR/Comm.(CLXXV) (March 5, 2009), http://www.peaceau.org/uploads/iccarrestwarranteng.pdf.

12 David Hoile, Justice Denied By THE ICC: The ReAlity of THE InTERnAtional Criminal Court 206 (2014).

${ }^{13}$ Assembly of the African Union, Thirteenth Ordinary Session, July 1-3, 2009, Decision on the Meeting of African States Parties to the Rome Statute of the International Criminal Court, in Decisions and Declarations, 910 , Assembly/AU/Dec.245 (XIII), http://goo.gl/7QiQ1S.

${ }^{14}$ Murithi, supra note 6 , at 3.

${ }^{15}$ HoILE, supra note 12, at 312-14 (providing a detailed account of the events precipitating the trials).
} 
resulted in more than 1,100 civilian deaths and the internal displacement of over 350,000 individuals. $^{16}$

The Kenyan government created the Commission to Investigate Post-Election Violence ("CIPEV") in February 2008, to investigate the events. ${ }^{17}$ President Kimbaki and Prime Minister Odinga sanctioned the Commission's creation and pledged in writing to implement its entire Report. ${ }^{18}$ At the conclusion of its investigation, the CIPEV produced a sealed list of suspects and a report identifying "planning and organization by businessman, politicians and others" as a cause of the violence. ${ }^{19}$ The CIPEV report also noted a cycle of impunity in Kenya, reflected in consistent failure to hold high-level government officials criminally responsible for their actions. ${ }^{20}$ The Report stated that a list of suspects would be delivered to the ICC Prosecutor unless the government established a new domestic court — a Special Tribunal for Kenya tasked with investigating the crimes and trying the perpetrators. ${ }^{21}$ The Kenyan Parliament never constituted the Tribunal. ${ }^{22}$

Accordingly, former U.N. Secretary-General Kofi Annan delivered the list of suspects to the ICC Prosecutor, whose request to initiate an independent investigation was granted in March 2010. The Pre-Trial Chamber confirmed charges against both Kenyatta ${ }^{23}$ and Ruto $^{24}$ in January 2012. The Chamber charged Ruto with the crimes against humanity of murder, deportation or forcible transfer

\footnotetext{
${ }^{16}$ Report of the Commission of Inquiry into the Post-Election Violence 293, 345 (Oct. 15, 2008) [hereinafter Waki Report] http://kenyastockholm.files.wordpress.com/2008/10/the-waki-report.pdf (last visited May 20, 2016).

${ }^{17} I d$. at vii. CIPEV is also referred to colloquially as the "Waki Commission."

${ }^{18}$ Catherine Akurut, Kenya: Involvement of the ICC in the 2007 Post-Election Violence, IN ON AFRICA (Oct. 2012), http://goo.gl/GVXDHV.

${ }^{19}$ Waki Report, supra note 16 , at 347.

${ }^{20}$ Id. at ix.

${ }^{21}$ Id. at 473 .

${ }^{22}$ How Kenya Handled Local Tribunal Process, DAILY NATION (Sept. 17, 2013), http://goo.gl/Nrhl6d (providing a detailed account of attempts to constitute the Tribunal). The narrative surrounding attempts to prosecute Kenyatta and Ruto domestically is developed in Part V(D), which follows.

${ }^{23}$ Case Information Sheet: The Prosecutor v. Uhuru Muigai Kenyatta, InTERnAtional CRIMINAL COURT (Mar. 13, 2015) [hereinafter Ruto Information Sheet], https://www.icc-cpi.int/iccdocs/PIDS/publications/KenyattaEng.pdf.

${ }^{24}$ Case Information Sheet: The Prosecutor v. William Samoei Ruto and Joshua Arap Sang, INTERNATIONAL CRIMINAL COURT (Sept. 18, 2013), https://www.icc-cpi.int/iccdocs/PIDS/publications/RutoKosgeySangEng.pdf.
} 
of populations, and persecution. ${ }^{25}$ The Court charged Kenyatta with crimes against humanity, including murder, rape, persecution, deportation or forcible transfer, and other inhumane acts. ${ }^{26}$

Initially, the ICC prosecutions enjoyed widespread public support in Kenya. ${ }^{27}$ But that support did not survive the defendants' 2013 presidential campaign. After the Pre-Trial Chamber confirmed the charges, Kenyatta and Ruto became political allies, forming the Jubilee Coalition in advance of the election. ${ }^{28}$ Public support for the trials persisted, ${ }^{29}$ however, and remained high in the months leading up to the vote. ${ }^{30}$ Accordingly, promises to cooperate with the ICC were a pillar of the defendants' campaign. ${ }^{31}$ The pair framed the indictments as a personal matter that would not interfere with their ability to govern. ${ }^{32}$ Yet even as the defendants pledged cooperation, Kenyatta and Ruto villainized the ICC as a tool of Western nations seeking to meddle in the Kenyan electoral process. ${ }^{33}$ This dual strategy_pledging cooperation while raising objections to the prosecution based on Kenya's sovereignty — allowed the defendants to avoid the appearance of shirking accountability while increasing public support for their anti-colonial narrative against the ICC.

Kenyatta and Ruto were elected as President and Deputy President of Kenya, respectively, on March 9, 2013. After the elections, public support for the trials declined precipitously. ${ }^{34}$ Reasons for the decline in public approval included: (1) Kenyatta and Ruto's election; (2) the Prosecutor's

\footnotetext{
${ }^{25} I d$.

${ }^{26}$ Ruto Information Sheet, supra note 24, at 1.

${ }^{27}$ Review Report, The Kenya National Dialogue And ReCOnCILIATION (KNDR) Monitoring ProjeCt 12 (October 2010), http://www.katibainstitute.org/Archives/images/KNDR\%20Review\%20Report\%202010.pdf.

${ }^{28}$ Alex Perry, Kenya's Election: What Uhuru Kenyatta's Victory Means for Kenya, Time (Mar. 9, 2013), http://world.time.com/2013/03/09/kenyas-election-what-uhuru-kenyattas-victory-means-for-africa/.

${ }^{29}$ D.H., Public Opinion in Kenya: Politics and Justice, The ECONOMIST (Oct. 10, 2012), http://www.economist.com/blogs/baobab/2012/10/public-opinion-kenya.

${ }^{30}$ Kenya's 2013 General Election: A Review of Preparedness, THE KENYA NATIONAL DiALOGUE AND RECONCILIATION (KNDR) MONitoring PRojeCt 26 (Feb. 2013), http://www.katibainstitute.org/Archives/images/KNDR\%20Review\%20Report\%202013.pdf.

${ }_{31}$ Michela Wrong, Indictee for President!, THE NEW YORK TIMES (Mar. 11, 2013) http://goo.gl/sbiLZf.

${ }^{32}$ Sarah McGregor, Kenya's Kenyatta, Facing ICC Charges, Wins Presidential Vote, BLOOMBERG NEWs (March 9 , 2013), http://goo.gl/Vsm9pF.

${ }^{33}$ Perry, supra note 28. For example, the campaign issued a statement expressing deep concern "about the shadowy, suspicious and rather animated involvement of the British High Commissioner in Kenya's election." Id.

${ }^{34}$ Kenya and the International Criminal Court: It's Show Time, THE ECONOMIST (Sept. 7, 2013) [hereinafter Show Time] http://goo.gl/RpUzuC.
} 
decision to drop the case against Francis Muthuara - the Head of Public Service and Secretary to the Cabinet; ${ }^{35}$ and (3) the trials' extensive delay. ${ }^{36}$ The defendants' also continued their Janus-faced strategy ${ }^{37}$ criticizing the ICC more pointedly, ${ }^{38}$ while continuing to emphasize their cooperation with the process. ${ }^{39}$

Ruto's trial opened on September 10, 2013. ${ }^{40}$ Kenyatta's was scheduled to begin on December 19, 2013; however, the Prosecutor requested a deferral until October 7, 2014, citing the Kenyan government's failure to provide requested evidence. ${ }^{41}$ That deferral was granted. A series of additional deferral requests followed. ${ }^{42}$ Finally, on December 5, 2014, the ICC Prosecutor withdrew the charges against Kenyatta, citing a lack of evidence. ${ }^{43}$ On October 26, 2015 Ruto moved for a judgment of acquittal. ${ }^{44}$ On April 5, 2016 the court dismissed the case against Ruto, citing insufficient evidence. $^{45}$

\footnotetext{
${ }^{35}$ The Kenyan government's recalcitrance, discussed in Section V(H), contributed to the withdrawal of the ICC indictment against Muthuara. The Prosecutor cited the Kenyan government's failure to help uncover evidence "that would have been crucial, or at the very least, may have been useful" as contributing to the case's dismissal. Prosecutor v. Francis Kirimi Muthuara and Uhuru Muigai Kenyatta, Case No. ICC-01/09-02/11, Prosecution Notification of the Withdrawal of Charges Against Francis Mirimi Muthuara, Office of the Prosecutor 6 (Mar. 11, 2013), https://www.icccpi.int/CourtRecords/CR2013_01871.PDF.

${ }^{36}$ Felix Olick, International Criminal Court Losing Public Support on Uhuru Kenyatta, William Ruto Trials, StANDARD DigiTAL 2 (April 25, 2013), http://goo.gl/xhv4yX; see also The ICC Issue and Raila's Political Future, IPSOS (July 2013), http://goo.gl/FPYGKO.

${ }^{37}$ Tomas Zak, Kenyatta in Court: The ICC Needs to Start Winning Some Public Perception Battles, AllAfrica (Nov. 12, 2013), http://allafrica.com/stories/201311121077.html.

${ }^{38}$ See, e.g., "Uhuru Kenyatta says ICC Trial no Longer a Personal Obligation," DAILY NATION (Oct. 14, 2013), http://goo.gl/1O9sSu.

${ }^{39}$ Uhuru Blasts US, UK in his AU Speech, NEWVISION (Oct. 13, 2013), http://goo.gl/VVUH3V. The complex relationship between these strategies and public opinion is discussed throughout.

${ }^{40}$ Case Information Sheet: The Prosecutor v. William Samoei Ruto and Joshua Arap Sang, supra note 24.

${ }^{41}$ Gabriele Steinhauser, International Criminal Court Delays Trial Against Kenya's President, THE WALL STREeT JOURNAL (Sept. 5, 2014), http://goo.gl/cIR5S2.

${ }^{42}$ Kenya Cases at the International Criminal Court: Timeline, InTERNATIONAL Justice MONITOR, http://www.ijmonitor.org/kenya-cases-timeline/ (last visited May 5, 2016).

${ }^{43}$ Prosecutor v. Uhuru Muigai Kenyatta, Case No. ICC-01/09-02/11, Notice of the Withdrawal of the Charges Against Uhuru Muigai Kenyatta, Office of the Prosecutor (Dec. 5, 2014), https://www.icccpi.int/CourtRecords/CR2014 09939.PDF.

${ }^{44}$ Prosecutor v. William Samoei Ruto and Joshua Arap Sang, Corrigendum of Ruto Defence Request for Judgment of Acquittal, ICC-01/09-01/11 (Oct. 26, 2015), https://www.icc-cpi.int/CourtRecords/CR2015_20293.PDF.

${ }^{45}$ Prosecutor v. William Samoei Ruto and Joshua Arap Sang, Decision on Defence Applications for Judgments of Acquittal, ICC-01/09-01/11 (April 5, 2016), https://www.icc-cpi.int/CourtRecords/CR2016 02617.pdf.
} 


\section{Identifying Different Instances of Backlash against the ICC}

International and domestic media reports from the last several years have been peppered with fragments of the Kenyan government's backlash against the ICC resulting from the Kenyatta and Ruto prosecutions. This section of the article puts those pieces together, presenting a narrative summary of the major instances of backlash against the ICC. ${ }^{46}$ The summary illuminates the striking diversity and range of backlash strategies. Some aspects of the government's campaign—such as lobbying the Security Council for a deferral, proposing amendments to the Rome Statute, and urging transfer to a national or regional judicial forum - appear to work within the framework of the ICC legal regime. But others - notably, threatening national and regional withdrawal from the Rome Statute, refusing to cooperate with the Prosecutor, and using rhetoric to politicize the trials - reveal the government's open hostility to the Court. Our review of seemingly discrete instances of backlash sets the stage for Part V, in which we explain how these efforts are part of a larger integrated backlash strategy marked by several unifying patterns.

\section{A. Lobbying the U.N. Security Council to Defer or Terminate the ICC Prosecutions}

Article 16 of the Rome Statute permits the UNSC to defer ICC investigations or prosecutions. ${ }^{47}$ With the backing of the African Union ("AU”), the Kenyan government filed two deferral requests with the Security Council, neither of which was granted. It also unsuccessfully asked the UNSC to terminate the ICC proceedings against Kenyatta and Ruto. At first blush, Kenya's

\footnotetext{
${ }^{46}$ See also Sosteness Francis Materu, The Post-Election ViOLEnCE In KenYA: Domestic AND InTERNATIONAL LEGAL RESPONSES 231-40 (2014) (providing a narrative account and analysis of several of these strategies, including threats of withdrawal from the Rome Statute, efforts to resort to regional criminal jurisdictions, and requests to the UNSC for deferral); Lionel Nichols, THE INTERNATIONAL CRIMINAL COURT AND THE END OF IMPUNITY IN KENYA 156 (2015) (providing a narrative account and analysis of several of these strategies in support of the thesis that Kenya's government constructed a "foreign affairs façade" by coupling backlash with shows of cooperation-one of the patterns identified in this Article in sub-section V(C)).

47 "No investigation may be commenced or proceeded with under this Statute for a period of 12 months after the Security Council, in a resolution adopted under Chapter VII of the Charter of the United Nations, has requested the Court to that effect; that request may be renewed by the Council under the same conditions." Rome Statute of the International Criminal Court, art. 16, U.N. Doc. A/CONF.183/9 (July 17, 1998), http://goo.gl/be0NIE.
} 
requests appeared to be genuine efforts to delay or end the prosecutions. In fact, as we now explain, Kenya anticipated the failure of all three requests. The government used each rejection to strengthen the narrative that the defendants' prosecutions were evidence of a deeper problem: Africa's marginalization by the West. That narrative politicized the ICC, undermining its legitimacy.

Kenya began pushing for an Article 16 deferral in late 2010, but did not submit a formal request at that time. ${ }^{48}$ Instead, Kenya gathered regional support for position to block the ICC prosecutions. The AU, at its Summit in January 2011, issued a Decision endorsing Kenya's attempt to obtain a UNSC deferral of the Kenyatta and Ruto cases. ${ }^{49}$ The AU's politically charged endorsement refers to several aspects of the mounting tensions between the ICC and the African regional body. First, the Decision notes the UNSC's failure to act on earlier AU requests to defer ICC proceedings against President al-Bashir. ${ }^{50}$ Second, it approves the Kenyan government's decision to receive al-Bashir during a visit to the country in $2010^{51}$ — despite his outstanding ICC arrest warrant $^{52}$ - as implementing AU Assembly decisions seeking to promote regional peace and security. Finally, the Decision reiterates the AU's support for an amendment to Article 16, proposed in 2009, and discussed below, to empower the UN General Assembly to pursue deferral where the UNSC "fails to act."."53

The AU Decision cites two primary reasons in support of a deferral: deference to national prosecutions in line with the principle of complementarity, and Kenya's critical role in ensuring

\footnotetext{
${ }^{48}$ Update Report Number 1: Kenya and the ICC, SECURITY COUNCIL REPORT (April 6, 2011), http://www.securitycouncilreport.org/update-report/lookup-c-glKWLeMTIsG-b-6717579.php.

${ }^{49}$ Assembly of the African Union, Sixteenth Ordinary Session, Jan. 30-31, 2011, Decision on the Implementation of the Decisions on the International Criminal Court, in Decisions, Declarations, and Resolution, - 6, Assembly/AU/Dec.332361(XVI) [hereinafter Sixteenth Session Decision], http://goo.gl/qXvsY1.

${ }^{50} \mathrm{Id}$. at 3 .

${ }^{51} \mathrm{Id}$. at 9 .

${ }^{52}$ Warrant of Arrest for Omar Hassan Ahmad Al Bashir, supra note 10.

${ }^{53}$ Sixteenth Session Decision, supra note 49, ๆ 6, 9. See also Max du Plessis \& Chris Gevers, Kenya's Deferral Request and the Proposed Amendment to Article 16 of the Rome Statute, EJIL: TALK! (Feb. 19, 2011) [hereinafter Deferral \& Article 16], http://goo.gl/FCyEe9 (discussing Kenya's proposed amendment to Art. 16).
} 
regional peace and security. ${ }^{54}$ The principle of complementarity is one of the hallmarks of the ICC's jurisdiction, reflecting the understanding that states have the primary responsibility to prosecute international crimes in their respective national legal systems. The ICC may commence an investigation only where a state is unwilling or unable to genuinely investigate and prosecute such crimes. The principle is also based on considerations of efficiency and effectiveness, since officials in the country where atrocities occurred generally have superior access to evidence and witnesses and the means to investigate and prosecute offenses. ${ }^{55}$ The AU's reference to complementarity to justify a deferral is thus linked to a broader narrative developed by Kenya to support its backlash against the ICC - that domestic or regional prosecutions are more legitimate than those in the Hague.

Following the AU decision, the Kenyan government formally requested a deferral on March 4, 2011. ${ }^{56}$ The Security Council addressed the request in an interactive dialogue two weeks later, expressing concern that Kenya's newly brokered Coalition government was not united in seeking a deferral. ${ }^{57}$ Kenya's Permanent Representative to the United Nations subsequently submitted a letter explaining that the Coalition government had reached a consensus on the issue, noting that the ODM Party no longer opposed deferral. Curiously, however, the ODM Party's Secretary subsequently sent a letter to the Council reiterating the party's opposition. ${ }^{58}$ Reportedly, several nations on the Council expressed a preference that Kenya pursue its grievances under Article 19 of the Rome Statute, the provision dealing with challenges to the ICC's jurisdiction and the admissibility of a case. ${ }^{59}$ After

\footnotetext{
${ }^{54} I d$. at 96 .

${ }^{55}$ Office of the Prosecutor, International Criminal Court, Informal Expert Paper: The Principle of Complementarity in Practice 3 (2003), https://goo.gl/jpQ1HS.

${ }^{56}$ Macharia Kama, Request of Kenya for Deferral under Article 16 of the Rome Statute of the International Criminal Court, United Nations Security Council, S/2011/201 (Mar. 23, 2011) [hereinafter Kamau Deferral Request] (discussing letter dated March 4, 2011, requesting deferral in 91 ), http://goo.gl/TTcFQ7.

${ }_{58}^{57}$ Update Report Number 1: Kenya and the ICC, supra note 48.

${ }_{59}^{58} \mathrm{Id}$.

${ }^{59} I d$.
} 
further consultations on April 8, 2011, the Security Council did not respond to the deferral requesta decision well within its discretion. ${ }^{60}$

Two years later, Kenya expanded its arguments to the Security Council against the prosecutions. On May 2, 2013, Kenya's Permanent Representative to the U.N. submitted a note verbale requesting the cases' immediate termination, stating: "What this delegation is asking for is not deferral. What this delegation is asking for is for the immediate termination of the case at the Hague without much further ado."61 The further stated that "[a] lot has changed in the past two and a half years; we submit that Kenya has the capacity to offer a home grown solution.",62

According to a senior Security Council diplomat, the legal basis for this argument is dubious: "The letter from the Kenyans is slightly bizarre because they are actually asking the Security Council to do something it has no authority to do," since it can, at most, defer the cases. ${ }^{63}$ The ICC Prosecutor also criticized the termination request as a "backdoor attempt to politicize the ICC process." 64 The proposal nevertheless received a warm reception from Rwanda's U.N. Ambassador, who praised the note as making a "compelling case against the methods of work of the Office of the Prosecutor" and lamented that the ICC failed to live up to the aspiration that the Court would "be independent from political interference" and "uphold the sovereign equality of States.",65

Interestingly, in his capacity as Deputy President, Ruto stated that the Permanent Representative's termination request did not in fact reflect the Kenyan government's position. ${ }^{66}$ This

\footnotetext{
${ }^{60}$ Chronology of Events: Kenya and the ICC, SECURITY COUNCIL REPORT (updated Dec. 13, 2013), http://www.securitycouncilreport.org/chronology/kenya.php (discussing meeting on April 8, 2011).

${ }^{61}$ Note Verbale from the Permanent Mission of the Republic of Kenya to the United Nations, No. 617/13 (May 3, 2013), http://councilandcourt.org/files/2012/11/KenyaNoteVerbale.pdf.

${ }^{62}$ Kenya Asks UN to Halt ICC Charges Against Kenyatta, BBC News AFrICA (May 9, 2013), http://www.bbc.com/news/world-africa-22472242.

${ }^{63}$ Chrispin Mwakideu, ICC Rejects Call for Kenya Charges to be Dropped, REUTERS (May 10, 2013), http://www.dw.de/icc-rejects-call-for-kenya-charges-to-be-dropped/a-16804121.

${ }^{64}$ Tom Maliti, Kenya Sends Mixed Signals on the ICC-Part 2, InTERNATIONAL Justice Monitor (June 2, 2013), http://www.ijmonitor.org/2013/06/kenya-sends-mixed-signals-on-the-icc-part-2/.

${ }^{65}$ Mark Kersten, A Bizarre Snowball's Chance in Hell: Kenya asks Security Council to Terminate Kenyatta Case at ICC, JUSTICE IN CONFLICT (May13, 2013), https://goo.gl/6igkZn.

${ }^{66}$ Kevin John Heller, An Unusual Dissenter from Kenya's Bid To Shut Down the ICC, OPINIO JURIS (May 11, 2013), http://opiniojuris.org/2013/05/11/an-unusual-dissenter-from-kenyas-bid-to-shut-down-the-icc/.
} 
sentiment was mirrored by Kenya's Attorney General. ${ }^{67}$ Commentators at the time voiced considerable skepticism about the Ambassador's authority to act unilaterally, speculating that the disavowals were intended to create a veneer of distance between the Kenyan government and efforts to resist the ICC process. ${ }^{68}$ That distance would have created an illusion of cooperation consistent with Ruto's campaign promises, an issue discussed further in Section V(C).

On May 13, 2013, the Security Council received a follow-up letter from Kenya requesting an interactive dialogue on the deferral request. At the dialogue, held on May 23, 2013, the UNSC again showed no inclination to intervene. Most Security Council members, including the United States, France and the United Kingdom, ${ }^{69}$ maintained that deferral was inappropriate because the prosecutions did not threaten international peace and security and because Kenya's grievances would be more appropriately addressed in future meetings of the ASP. ${ }^{70}$

The African Union responded four days later by adopting a "Decision on Africa's Relationship with the International Criminal Court." ${ }^{, 71}$ The decision reiterated the AU's claim of complementarity - that "Kenya has primary jurisdiction over the investigations and prosecutions of crimes in relation to the 2007 post-election violence"-and the need to defer the cases in light of Kenya's role in preserving national and regional peace and stability. ${ }^{72}$

The deferral issue arose for a third time in October 2013 when the AU debated whether African states should withdraw en masse from the Rome Statute, an issue discussed in Section

\footnotetext{
${ }^{67}$ Lordrick Mayabi, AG Disowns Application to UN Security Council, CAPITAL News (May 11, 2013), http://www.capitalfm.co.ke/news/2013/05/ag-disowns-application-to-un-security-council/.

${ }^{68}$ Heller, supra note 66.

${ }^{69}$ Mark Kersten, Kenya and the ICC: Coming to a Head?, Justice In CONFLiCT (Nov. 19, 2013). http://justiceinconflict.org/2013/11/19/kenya-and-the-icc-coming-to-a-head/.

${ }^{70}$ Interactive Dialogue with AU Contact Group and Kenya on ICC Deferral, WHAT's In BLUE (Oct. 30, 2013), http://www.whatsinblue.org/2013/10/interactive-dialogue-with-au-contact-group-and-kenya-on-icc-deferral-1.php.

${ }^{71}$ Assembly of the African Union, Twenty-First Ordinary Session, May 26-27, 2013, Decision on International Jurisdiction, Justice and the International Criminal Court (ICC), in Decisions, Declarations, and Resolution, 96 , Doc. Assembly/AU/Dec.474-489 (XXI), http://iccnow.org/documents/AU_decisions_21st_summit_May_2013.pdf.

${ }^{72}$ Id . at 7 .
} 
IV(C). ${ }^{73}$ The final AU Decision, adopted on October 12, did not call for mass withdrawal; instead it stated that Kenya should again seek a deferral from the UNSC, ${ }^{74}$ which Kenya did in a second formal deferral request a few days later. ${ }^{75}$ The same AU decision also requested that the ICC suspend the proceedings until the UNSC had considered the request, ${ }^{76}$ and further asserted that until such time President Kenyatta would not appear before the ICC. ${ }^{77}$

The UNSC held a vote on a draft resolution on the Kenya deferral request on November 15, $2013 .^{78}$ The resolution received seven affirmative votes, two short of the nine votes required for adoption. ${ }^{79}$ Of the ten rotating members, five-Argentina, Australia, Guatemala, Luxembourg and Republic of-abstained. The five other members-Azerbaijan, Morocco, Pakistan, Rwanda and Togo - voted in favor of adoption. Three permanent members - the United States, United Kingdom and France — abstained; China and Russia, voted in favor.

There is strong evidence that Kenya pressed the UNSC to vote on the draft resolution although it expected that its efforts would fail. At an interactive dialogue with the AU Contact Group held in late October, a majority of Security Council members expressed their opposed to the deferral request. ${ }^{80}$ It thus appears that Kenya's objective was to link its deferral request to broader criticisms

\footnotetext{
${ }^{73}$ Ibrahim Tommy, Africa's Unfinished Business: Ensuring Justice for Victims of Serious International Crime, in Reflections on the African Union ICC Relationship, AFRICAN NETWORK ON INTERNATIONAL CRIMINAL JUSTICE 3 q 1 (January 2014) http://goo.gl/DWbbBd.

${ }^{74}$ Assembly of the African Union, Extraordinary Session, Oct. 12, 2013, Decision on Africa's Relationship with the International Criminal Court (ICC), in Decisions and Declarations, $110(\mathrm{ix})$, Doc. Ext/Assembly/AU/Dec.1-2 (Oct.2013), http://www.iccnow.org/documents/Ext Assembly AU Dec Decl 12Oct2013.pdf.

${ }^{75}$ Identical Letters Dated October 21, 2013 from the Permanent Representative of Kenya to the United Nations Addressed to the Secretary General and President of the Security Council (Oct. 22, 2013), http://goo.gl/jEc812.

${ }^{76}$ Decision on Africa's Relationship with the International Criminal Court (ICC), supra note 74, at 910 (ix).

${ }^{77} \mathrm{Id}$. at $910(\mathrm{x})$.

${ }^{78}$ The draft resolution was submitted jointly by twelve African states and Azerbaijan. Security Council Doc. S/2013/660 (Nov. 15, 2013), at http://www.securitycouncilreport.org/atf/cf/\%7B65BFCF9B-6D27-4E9C-8CD3CF6E4FF96FF9\%7D/s_2013_660.pdf.

${ }^{79}$ United Nations Security Council, Security Council Resolution Seeking Deferral of Kenyan Leader's Trials Fails to Win Adoption, With 7 Voting in Favor, 8 Abstaining, Security Council 7060 ${ }^{\text {th }}$ Meeting (AM), Doc. SC/11176 (Nov. 15 , 2013) [hereinafter Deferral Failure], http://www.un.org/News/Press/docs/2013/sc11176.doc.htm.

${ }^{80}$ Id. See also AU Request for ICC Deferral of Kenyan Situation, WHAT’S IN BLUE? (Nov. 13, 2013), http://www.whatsinblue.org/2013/11/au-request-for-icc-deferral-of-kenyan-situation.php.
} 
that the Security Council does not give sufficient credence to the views of African governments. ${ }^{81}$ That position was confirmed by Tekeda Alemu, who, speaking as the Chair of the AU, remarked that the decision illustrated distrust in African leaders. ${ }^{82}$ The vote may also have advanced Kenya's efforts, discussed in Section IV(D), to distract the international community from the fact thatdespite the emphasis its deferral requests placed on complementarity - the government was not, in fact, making meaningful efforts to investigate the defendants' crimes.

The doubtful legal viability of a deferral request rooted in complementarity provides additional evidence to support the strategic nature of the deferral requests. Although deferral requests by both the Kenyan government and the African Union repeatedly cite complementarity, Chapter VII of the U.N. Charter provides only for Security Council action precipitated by threats to the peace, breaches of the peace, and acts of aggression. ${ }^{83}$ Commentators have asserted that because complementarity is not linked to any of these events, it does not provide a valid legal basis for an Article 16 deferral. ${ }^{84}$ The requests' emphasis on complementarity notwithstanding its weak legal basis is thus consistent with furthering a broader political narrative framing the ICC as a tool of Western powers and a threat to Kenya's sovereignty. ${ }^{85}$

Kenya and the AU, however, seem to consider deferral an open issue. As recently as October 20, 2015, Kenya's Permanent Ambassador to the UN submitted a letter to the UNSC requesting deferral pending an audit of the witnesses against Ruto. The letter emphasized that the AU remains "actively seized" of the "unresolved" matter and reiterated that the "serious political and social

\footnotetext{
${ }^{81}$ Michelle Nichols, Africa Fails to Get ICC Trials Deferred at United Nations, ReUTERS (Nov. 15, 2013) at http://www.reuters.com/article/2013/11/15/us-kenya-icc-un-idUSBRE9AE0S420131115.

${ }^{82}$ Deferral Failure, supra note 79.

${ }^{83}$ Chapter VII, Charter of the United Nations, June 26, 1945, 59 Stat. 1031, T.S. No 993, http://goo.gl/G5xA6g. See also Africa, the UNSC and the ICC: The Question of Deferrals, in AFRICA AND THE INTERNATIONAL CRIMINAL COURT 195, 206 (Gerard Werle, ed. 2014) (assessing the merits of the deferral requests and concluding that the situations did not merit an Article 16 intervention).

${ }^{84}$ Deferral \& Article 16, supra note 53. See also Hemi Mistry \& Deborah Verduzco, The UN Security Council and the International Criminal Court, CHATHAM HOUSE (Mar. 16, 2012), http://goo.gl/vP7Dcu. ${ }^{85} I d$.
} 
distraction" caused by the prosecutions continues to undermine the "immediate and long term political stability" of Kenya and the Horn of Africa." 86

B. Motions by the Kenyan Parliament to Withdraw from the Rome Statute

Following the ICC indictments of Kenyatta and Ruto, the National Assembly of Kenya adopted two motions to withdraw from the Rome Statute and to repeal domestic legislation proscribing the crimes within the ICC's jurisdiction. Both motions were direct reactions to the prosecutions - one came a week after the suspects were named and the second preceded an AU Summit discussing an en masse withdrawal of African nations from the ICC. Although neither motion was approved, as public demonstrations of the desire of many Kenya legislators to withdraw from the Rome Statute, the motions helped garner support for the African-wide ICC withdrawal proposal discussed below.

Article 127 provides for the withdrawal of a state that had previously ratified the Rome Statute. ${ }^{87}$ However, neither of the Kenyan Parliament's withdrawal motions could have undermined the legal basis for prosecuting Kenyatta or Ruto. ${ }^{88}$ The investigations began when Kenya was a party to the Rome Statute, and Article 127 expressly provides that withdrawal affects neither "proceedings in relation to which the withdrawing State had a duty to cooperate and which were commenced prior to the date on which the withdrawal became effective," nor "continued consideration of any matter which was already under consideration by the Court." 89

Nevertheless, Kenya's withdrawal would likely have had a major prospective impact on the Court. As one of the most powerful African states, the country's denunciation of the Rome Statute

\footnotetext{
${ }^{86}$ Maureen Murimi, Defer ICC Cases, Kenya Tells UN Security Council, CiTIZEN DigiTAL (Oct. 23, 2015), https://goo.gl/USfWcq.

${ }^{87}$ Rome Statute of the International Criminal Court, Article 127: Withdrawal, International Criminal Court, http://www.icc-cpi.int/iccdocs/PIDS/publications/RomeStatutEng.pdf.

${ }^{88}$ See, e.g., MG Zimeta, What Kenya's Withdrawal Means for the International Criminal Court, THE GUARDIAN (Sept. 6, 2013), http://www.theguardian.com/commentisfree/2013/sep/06/kenya-withdrawal-icc-credibility.

${ }^{89}$ Rome Statute, supra note 87, art. 127.
} 
would have sent a strong political message. Given the link that the Kenyan government consistently drew between the "West" and the ICC, withdrawal would have contributed to the perception of the West's declining relations with an economically up-and-coming Kenya, a particularly salient issue in light of improving economic ties between Kenya and China. ${ }^{90}$

The Parliament's first motion to withdraw from the Rome Statute and to repeal the International Crimes $\mathrm{Act}^{91}$ passed a week after the naming of the suspects in the post-election violence. ${ }^{92}$ The motion, which followed several failed attempts to pass a bill create a Special Tribunal for Kenya, ${ }^{93}$ emphasized that, in light of the 2010 constitutional reforms, the cases against the suspects should be tried domestically. ${ }^{94}$ Although the motion passed overwhelmingly in Parliament, it was never acted upon by then-President Kibaki.

A second motion, which followed the 2013 elections, also urged immediate withdrawal from the Rome Statute and the repeal of the International Crimes Act. ${ }^{95}$ This motion reiterated that the constitutional reforms had created a competent national judiciary and emphasized the lawful election of Kenyatta and Ruto. ${ }^{96}$ The motion's sponsor also cited the need to protect Kenya's sovereignty, the increasing politicization of the ICC, and the refusal of Western powers, including the United States, to sign the Rome Statute. ${ }^{97}$ These rationales for withdrawal suggests concern that the indictments would interfere with the defendant's constitutional responsibilities and, thereby, demonstrate a lack of respect for the Kenyan people's political will. The motion thus bolstered the narrative that the

\footnotetext{
${ }^{90}$ Teddy Ng, Kenya Looks to 'Sincere Friend' in China, Southern China Morning Post (Aug. 19, 2013), http://goo.gl/JLSzX7.

${ }^{91}$ Republic of Kenya National Assembly, Motions 2010 (Dec. 22, 2010) [hereinafter 2010 Motion], file:///C:/Users/Anne/Downloads/Motion\%20Tracker\%202010\%20as\%20at $\% 2022-12-10 \% 20(2)$.pdf.

${ }_{92}$ Kenya MPs Vote to Leave ICC Over Poll Violence Claims, BCC News AfriCA (Dec. 23, 2010) at http://www.bbc.com/news/world-africa-12066667.

${ }^{93}$ Charles C. Jalloh, Kenya Should Reconsider Proposal to Withdraw from ICC, JURIST (Sept. 13, 2013), http://www.jurist.org/forum/2013/09/charles-jalloh-kenya-icc.php.

${ }^{95}$ Republic of Kenya National Assembly, Eleventh Parliament Bills 2013 at 105, file:///C:/Users/Anne/Downloads/Motions\%20Tracker\%2020\%20Dec\%202013\%20(2).pdf. 
ICC's refusal to allow Kenya to investigate the cases itself reflected both a lack of respect for its sovereignty and the Court's Western bias.

Additionally, the Parliament considered the 2013 motion shortly before the AU's discussion of an en masse African withdrawal from the ICC. ${ }^{98}$ The motion's adoption increased the credibility of the collective withdrawal threat. After its passage, Kenya secured the two-thirds majority required to convene an AU Extraordinary Summit to consider the matter. ${ }^{99}$ The prospect of Kenya's withdrawal also reinforced the regional political conversation framing the ICC as a neo-colonial tool, a theme first raised in response to the al-Bashir case. ${ }^{100}$

Under the Kenyan Constitution, the President must assent to bills passed by Parliament to complete the legislative process. ${ }^{101}$ President Kenyatta did not act on the 2013 motion ${ }^{102}$ — perhaps because of his election campaign platform promising to cooperate with the ICC. ${ }^{103}$ The decision distanced Ruto and Kenyatta from backlash efforts by the legislative branch. So did the removalduring debate - of language urging the suspension of "any links, cooperation and assistance with the International Criminal Court." 104 Such shows of cooperation bolstered the pair's domestic popularity, thereby making later attacks on the ICC more potent. ${ }^{105}$

Kenya's governmental structure facilitated the country's ability to broadcast strategically discordant messages about the ICC. The Parliament's adoption of the motions and the government's support for an AU Extraordinary Summit signaled Kenya's willingness to withdraw from the Rome

\footnotetext{
${ }^{98}$ Heidi Vogt, Kenyan Parliament Votes to Withdraw from International Criminal Court, THE WALL STREET JOURNAL (Sept. 5, 2013), http://goo.gl/419cXJ.

${ }^{99} \mathrm{Id}$.

${ }^{100}$ Jess Kyle, Kenya's ICC Withdrawal: The Wrong Face for the Kenya, JuRIST (Oct. 8, 2013) at http://jurist.org/dateline/2013/10/jess-kyle-icc-kenya.php.

${ }^{101}$ The Legislative Process, KENYA LAW, http://kenyalaw.org/k1/index.php?id=528.

102 Jason Straziuso and Tom Odula, Kenya Moves to Leave International Criminal Court, THE WASHINGTON POST (Sept. 5, 2013), https://goo.gl/8zmE3x.

103 See, e.g., Edmund Blair, Kenyatta, Indicted by ICC, Says Will Cooperate with International Bodies, REUTERS (Mar. 9, 2013), http://uk.reuters.com/article/2013/03/09/uk-kenya-elections-speech-idUKBRE9280AJ20130309.

${ }^{104}$ Mark Kersten, Kenya's Withdrawal from the ICC-An Act in Vain?, JustiCE IN CONFLICT (Sept. 6, 2013), http://justiceinconflict.org/2013/09/06/kenyas-withdrawal-from-the-icc-an-act-in-vain/.

${ }^{105}$ Olick, supra note 36.
} 
Statute. Yet even as the Parliament rejected the trials on the behalf of the people, President Kenyatta, in keeping with his campaign promises, declined to reject them as head of the executive branch. The veneer of cooperation that Kenyatta and Ruto maintained prevented the government from appearing indefensibly uncooperative. This facilitated the generation of regional support for the masse withdrawal proposal and also allowed the two officials to simultaneously mobilize- but divorce themselves from-other anti-ICC lobbying efforts.

C. En Masse Withdrawal from the Rome Statute

Kenya proposed an Extraordinary Summit on the ICC in October 2013 after the passage of its second motion to withdraw from the Rome Statute. At the Summit, AU members discussed the possibility of an en masse withdrawal from the Rome Statute but, as explained below, ultimately decided against this. Instead, the AU adopted two resolutions challenging the ICC prosecutions of Kenyatta and Ruto - that Heads of State should be immune from international prosecution during their terms of office, and that Kenya should request a deferral of the ICC proceedings from the UNSC.

Kenyan officials led the charge for an en masse AU withdrawal, requesting the meeting and securing the two-thirds majority vote required to call an Extraordinary Summit. ${ }^{106}$ Reportedly, Kenyan diplomats traveled throughout the continent to solicit other countries' support. ${ }^{107}$ Their efforts were aided by the fact that thirty-four of the African Union's fifty-four member states are parties to the Rome Statute. ${ }^{108}$

\footnotetext{
${ }^{106}$ Solomon Dersso, African Union Summit on the ICC - Extraordinary Solidarity of Elites (Oct. 12, 2013), http://solomondersso.wordpress.com/2013/10/12/the-trouble-with-african-leadership-solidarity-for-self-protection/. ${ }^{107}$ Ludger Schadomsky, The African Union Debates Its Relationship with the International Criminal Court, DW (Oct. 11, 2013), http://goo.gl/hFFHwa.

${ }^{108}$ Michelle McKenna, African Union Requests Security Council to Defer Cases of Kenyatta and Ruto, Human Security Centre (Oct. 18, 2013), http://www.hscentre.org/sub-saharan-africa/african-union-requests-security-council-to-defercases-of-kenyatta-and-ruto/.
} 
At the Summit, President Kenyatta gave an impassioned speech, declaring that the ICC "stopped being the home of justice the day it became the toy of declining imperial powers." 109 Kenyatta further lambasted the prosecutions as an affront to African sovereignty, stating: "These interventions go beyond internal interference with the affairs of a sovereign State. They constitute a fetid insult to Kenya and Africa. African sovereignty means nothing to the ICC and its patrons."110

Kenyatta also attempted to galvanize other AU member states by emphasizing that the U.S. and U.K. had refused to join the Rome Statute due to sovereignty concerns and fears of political prosecutions. He used this charge to argue that the Court "performs on the cue of European and American governments against the sovereignty of African States." ${ }^{\prime 11}$ Yet Kenyatta simultaneously emphasized his cooperation with the ICC, stating: "From the beginning of the cases I have fully cooperated with the Court . . I have attended court whenever required and complied with every requirement made of me in connection with my case."112 The AU press release struck a similar theme, asserting that "throughout this difficult period, Kenya has, in word and in deed expressed its willingness to cooperate with the [ICC]."113

A vote on masse withdrawal was held, but the proposal failed to garner the required two-thirds majority. No official tally of the votes was released. ${ }^{114}$ However, reports suggested a divide between Anglophone nations, which largely supported withdrawal, and Francophone nations, which largely opposed. ${ }^{115}$ According to these reports the nations supporting masse withdrawal included Ethiopia,

\footnotetext{
${ }^{109}$ Nicholas Kulish \& Benno Muchler, African Union Urges International Court to Delay Kenyan President's Trial, NEW YORK TiMES (Oct. 12, 2013), http://goo.gl/h2GKy0.

${ }^{110}$ President Uhuru Hits out at the West over ICC: Speech by his Excellency Hon. Uhuru Kenyatta, DAILY NATION (Oct. 12, 2013), http://goo.gl/cbhblJ.

${ }^{111} I d$.

${ }^{112} \mathrm{Id}$.

113 African Union, Africa to Request Deferment of Indictments Against Kenyan President and Vice President, Press Release No. 177/ 2013 (Oct. 12, 2013).

${ }^{114}$ See AU Summit To Decide Whether to Exit from ICC, AFRICA REVIEW (Oct. 9, 2013), http://goo.gl/26Vrno. This accords with the AU press release emphasizing that the AU intended to "quash rumors" that a mass withdrawal was planned. Africa to Request Deferment of Indictments Against Kenyan President and Vice President, supra note 109.

${ }^{115}$ Bernard Namunane, Why African Leaders Failed to Strike Deal on ICC in Ethiopia, DAILY NATION (Oct. 13, 2013), http://goo.gl/hEiGyG.
} 
Ghana, Kenya, Malawi, Sudan, Uganda and Zimbabwe, while the countries opposed included the Ivory Coast, Gambia, Mali and Botswana. ${ }^{116}$ According to a report by ThinkAfricaPress, the latter nations cited past failures to confront impunity as a reason to continue engaging with the ICC. ${ }^{117}$ However, the AU members voted in favor of giving immunity to sitting Heads of State, a backlash strategy discussed below in subsection F(3), and endorsed Kenya's pursuit of an Article 16 deferral, discussed above in subsection A.

\section{Attempts to Prosecute International Crimes Before Domestic Courts}

The ICC indictments followed multiple unsuccessful attempts in the Kenyan Parliament to constitute a Special Tribunal for Kenya. The Kenyan government nevertheless took the position that the ICC proceedings infringed on the nation's right to investigate and prosecute international crimes at home and shirked the Court's responsibility to expand Kenya's capacity to try such cases domestically.

The CIPEV Report set a deadline for establishing a Special Tribunal for Kenya. It required that representatives sign an agreement to establish the Special Tribunal within sixty days of the Report's publication, and that a statute incorporating the agreement come into force within an additional forty five days. If the Tribunal were not constituted by that date, the CIPEV would hand over the names of the suspects listed in the report to the ICC Prosecutor. The outlook for creating a Special Tribunal initially seemed positive, but ultimately the Parliament did not adopt any of the bills to establish the court. ${ }^{118}$

\footnotetext{
${ }^{116}$ James Bullock, AU and the ICC-How They Voted, THINK AFrICA PRESS (Oct. 15, 2013), http://allafrica.com/stories/201310150876.html.

${ }^{118}$ Lionel Nichols, ICC Prosecutor Seeks Permission to Investigate Kenyan Crimes Against Humanity, EJIL: TALK! (Nov. 17, 2009), http://goo.gl/8Ea1xW.
} 
The National Assembly failed to adopt the first bill to create a Special Tribunal, together with the Constitutional reforms required to make it viable, in February $2009 .{ }^{119}$ UN Secretary-General Kofi Annan twice extended the Report's deadline to facilitate the Tribunal's creation. ${ }^{120}$ In August 2009 a second bill was proposed, but never debated due to the lack of a Parliamentary quorum. No subsequent attempt to establish a Tribunal received a quorum.

The government also proposed that a Truth and Justice Reconciliation Commission investigate the post-election violence. The Commission was originally created to investigate and accurately record human rights violations that occurred between 1963 and 2008 - a window that included the post-election violence. ${ }^{121}$ However, the Commission could, at most, recommend prosecution, and the CIPEV had already taken that action. ${ }^{122}$

As the ICC investigation advanced, the executive branch came under increasing pressure to provide a domestic forum to investigate the post-election atrocities. ${ }^{123}$ One day before the ICC Prosecutor was scheduled to name the suspects, President Kibaki announced that a "local judicial mechanism" would be established to investigate the violence. ${ }^{124}$ The government subsequently challenged the admissibility of the Kenyatta and Ruto cases under Article 19.2(b) of the Rome Statute on the grounds that the post-election violence was being investigated domestically. ${ }^{125}$ In fact, there

\footnotetext{
${ }^{119}$ Antonina Okuta, National Legislation for Prosecution of International Crimes in Kenya, 7 J. INT'L CRIM. JUST. 1063 (2009) [hereinafter National Legislation for Crimes], http://goo.gl/yoF6Q4.Though it had the support of a slight majority, it did not garner the required two-thirds vote. Id. The bill was rejected by a vote of 101 to 93 . Office of the Prosecutor, Statement on the Situation in Kenya 97 (Aug. 14, 2013), http://goo.gl/qXJna6.

${ }^{120}$ Kenya: Swiftly Enact Special Tribunal, Human Rights Watch (Mar. 25, 2009), http://goo.gl/88k65H.

${ }^{121}$ National Legislation for Crimes, supra note 119at 1070-71.

${ }^{122}$ Id. Commentators observed that political elites "vacillated between the options, unsure of which would safeguard their own agendas: Trials in The Hague or local trials; trials in the Special Tribunal or before National Courts; and/or the TJRC." Godfrey M. Musila, Options for Transitional Justice in Kenya: Autonomy and the Challenge of External Prescriptions, 3 INT'L J. TRANSITIONAL JUST. 445, 450 (2009).

${ }^{123}$ Kenya to Establish Local Judicial Mechanism to Probe Violence, THE HaGue JustiCE PoRTAL (Dec. 14, 2010), http://www.haguejusticeportal.net/index.php?id=12321.

${ }^{124}$ World Report 2012: Kenya Events of 2011, Human Rights Watch [hereinafter World Report 2012] http://www.hrw.org/world-report-2012/world-report-2012-kenya.

${ }^{125}$ Prosecutor v. Francis Kirimi Muthuara, Uhuru Muigai Kenyatta And Muhammad Hussein Ali, Decision on the Application by the Government of Kenya Challenging the Admissibility of the Case Pursuant to Article 19(2)(b) of the Statute, ICC-01/09-02/11 (May 30, 2011) [hereinafter Kenyatta Admissibility Decision], http://goo.gl/hY55KF;

Prosecutor v. William Samoei Ruto, Henry Kiprono Kosgey, and Joshua Arap Sang, Decision on the Application by the
} 
is little evidence that police thoroughly investigated most of the crimes perpetrated by lower-level officials - let alone crimes allegedly committed by Kenyatta and Ruto - during the post-election violence. ${ }^{126}$ Moreover, any attempt to prosecute offenders for crimes against humanity would have been futile, since the recently adopted law proscribing that offense was not retrospective. ${ }^{127}$

The government also highlighted the 2010 constitutional reforms as proof of Kenya's competence to investigate and prosecute the post-election violence. ${ }^{128}$ For example, after the first motion to withdraw from the Rome Statute passed the Kenyan Parliament in 2010, President Kibaki introduced several reforms, including nominating a new Chief Justice, Deputy Chief Justice and Director of Public Prosecutions. ${ }^{129}$ However, Parliament later declared the appointments unconstitutional.

Ultimately, the ICC Pre-Trial Chamber rejected the defendants' Article 19 admissibility challenge to the prosecutions. The Court found, ${ }^{130}$ and independent reports reiterated, ${ }^{131}$ that Kenya failed to demonstrate that it was both capable of and had the political will to prosecute Kenyatta and Ruto domestically (as opposed to investigating other aspects of the post-election violence). On appeal, Kenya submitted a letter from the Director of Criminal Prosecutions stating that the government had conducted thirty-five interviews and reviewed documents and had thus far found

\footnotetext{
government of Kenya Challenging the Admissibility of the Case Pursuant to Article 19(2)(b) of the Statute, ICC-01/0901/11, (May 30, 2011) [hereinafter Ruto Admissibility Decision], http://goo.gl/ggmYFt.

${ }^{126}$ Turning Pebbles: Evading Accountability for Post-Election Violence in Kenya, HUMAN RIGHTS WATCH 46-49 (Dec. 9, 2011), https://goo.gl/7qQG9G (discussing the fact that police failed to thoroughly investigate many of the middle and lower level crimes). Kenya: Victims Still Seeking Justice for the Post-Election Violence, AMNESTY InTERNATIONAL (July 15, 2014), https://goo.g1/IUk8GS (discussing the fact that of the few cases investigated only a few were brought). ${ }^{127}$ Kenya's Post Election Violence Suspects Must be Brought to Justice, AMNESTY INTERNATIONAL (Nov. 6, 2009), https://goo.gl/oQcKDI. Kenya International Crimes Act (2008), https://www.issafrica.org/anicj/uploads/Kenya_International_Crimes_Act_2008.pdf.

${ }^{128}$ World Report 2012, supra note 124.

${ }^{129}$ Kenya Human Rights Commission Statement on the ICC and the President's Judicial Appointments, KenYa Human RighTS COMMission (Feb. 9, 2011), http://goo.gl/wFqw91. Civil society groups successfully contested the appointments as breaches of the constitutionally prescribed consultative appointment process, alleging that the appointments were meant to delay the ICC prosecutions. World Report 2012, supra note 124.

${ }^{130}$ See, e.g., Ruto Admissibility Decision, supra note 125.

${ }^{131}$ World Report 2012, supra note 124.
} 
insufficient evidence to charge the defendants. ${ }^{132}$ However, the ICC Appeals Chamber held that "it is not sufficient merely to assert that investigations are ongoing." Moreover, "unless investigative steps are actually taken in relation to the suspects who are the subject of the proceedings before the Court, it cannot be said that the same case is (currently) under investigation by the Court and by a national jurisdiction . . ."133

The admissibility ruling did not, however, deter the Kenyan government from waging a blistering political campaign against the ICC, alternately accusing the Court of failing to adequately equip Kenya to try the cases locally ${ }^{134}$ and, somewhat inconsistently, failing to acknowledge Kenya's desire to "move on." ${ }^{355}$ Kenya's Attorney General, for example, asserted that the Court's failure to help Kenya build capacity to prosecute lower-level crimes evidenced a lack of respect for its sovereignty. And Kenya's Director of Public Prosecutions, in a 2013 statement to the ICC Assembly of States Parties, unfavorably compared the ICC's activities in Kenya with the operation of the ICTR in Rwanda, stating: "Rwanda is now able to prosecute genocide suspects because they were assisted to build their legal and institutional framework. ICC has done zero for Kenya in that regard, yet that is among the things we would demand and expect from the Court."136

The AU also supported Kenya's demands for a domestic investigation of Kenyatta and Ruto. ${ }^{137}$ Beginning in 2001, the AU adopted the first of several Decisions tying the ICC proceedings

\footnotetext{
${ }^{132}$ See Annex I: Letter from Director of Criminal Investigation, in Filing of Annexes and Materials to the Application of the Government of Kenya Pursuant to Article 19 of the Rome Statute, (ICC-01/09-01/11-64) April 21, 2011), https://www.icc-cpi.int/CourtRecords/CR2011 04517.PDF.

${ }^{133}$ Prosecutor v. Francis Kirimi Muthuara, Uhuru Muigai Kenyatta and Muhammad Hussein Ali, Judgment on the Appeal of the Republic of Kenya Against the Decision of the Pre-Trial Chamber II of 30 May 2011 Entitled: Decision on the Application by the government of Kenya Challenging the Admissibility of the Case Pursuant to Article 19(2)(b) of the Statute, ICC-01/09-02/11-274, (Aug. 30, 2011), https://goo.gl/3VZlWp.

${ }^{134}$ Joseph Akwiri, Kenya: ICC Accused of Failing Kenyan Courts, ALL AFRICA (Dec. 17, 2013), http://allafrica.com/stories/201312181009.html.

${ }^{135}$ Perceptions and Realities: Kenya and the International Criminal Court, Human Rights Watch (Nov. 2013), http://www.hrw.org/news/2013/11/14/perceptions-and-realities-kenya-and-international-criminal-court\#2.

${ }^{136}$ Akwiri, supra note 134.

${ }^{137}$ Assembly of the African Union, Seventeenth Ordinary Session, June 30-July 1, 2011, Decision on the Implementation of the Assembly Decisions on the International Criminal Court, in Decisions, Declarations, and Resolution, Assembly/AU/Dec.363-390 (XVII), http://goo.gl/wOu0HM.
} 
to the powerful evolving narrative of the ICC as a political institution engaged in "race hunting.","138 During the 2013 Session, the AU issued a Decision supporting the deferral of the Kenyatta and Ruto cases and advocating the creation of an African Court of Human and Peoples' Rights to try international crimes. ${ }^{139}$ The Decision generated significant political pressure, reaffirming cumulative language accusing the ICC of bias in AU Decisions dating back to 2009—well before the Kenyatta and Ruto prosecutions. ${ }^{140}$ Following the 2013 Decision, AU officials wrote to the ICC to request that the prosecutions be halted pending a response to the organization's demand that the cases be tried domestically. $^{141}$

\section{E. Proposals to Prosecute International Crimes Before Regional Courts}

The AU also attempted to establish a regional tribunal to prosecute international crimes. However, insofar as arguments for regional prosecutions advocated a transfer of the proceedings against Kenyatta and Ruto, they were clearly political rather than legal— the Rome Statute does not provide a mechanism for the ICC to transfer ongoing prosecutions.

Although proposals for an African court with jurisdiction over international crimes date back to $2004,{ }^{142}$ the drive to undermine the ICC prosecutions of Kenyatta and Ruto reinvigorated these initiatives. ${ }^{143}$ In 2008, the AU adopted a Protocol establishing the African Court of Justice and Human Rights (“ACJHR"). ${ }^{144}$ Two years later, the AU Commission appointed consultants to propose

\footnotetext{
138 African Leaders Accuse ICC of Race Hunt, AlJAZEERA (May 28, 2013), http://www.aljazeera.com/news/africa/2013/05/201352722331270466.html. ${ }_{139}$ Decision on Africa's Relationship with the International Criminal Court (ICC), supra note 74, at 910 (iv).

${ }^{141}$ African Union, Letter to the President of the International Criminal Court (Sept. 10, 2013) (referring to letter dated July 8, 2013) http://www.icccpi.int/en menus/icc/press\%20and\%20media/press\%20releases/Documents/pr943/130910-AU-letter-to-SHS.pdf. ${ }^{142}$ Max du Plessis, Implications of the AU Decision to give the African Court Jurisdiction over International Crimes, INSTITUTE FOR INTERNATIONAL SECURITY STUDIES 2 (June 2012), https://goo.gl/vI2xRE.

${ }^{143} I d$. at 4.

${ }^{144}$ Sonya Sceats, Africa's New Human Rights Court: Whistling in the Wind?, CHATHAm HousE 1 (March 2009), http://www.chathamhouse.org/sites/files/chathamhouse/public/Research/International\%20Law/bp0309sceats.pdf.
} 
amendments to give the ACJHR the power to try international crimes. ${ }^{145}$ In June 2014 , the AU approved an amendment to the ACJHR Protocol granting sitting Heads of State immunity before the not-yet-operational regional court. ${ }^{146}$ As amended, Article 46(a)bis provides that the Heads of State or Government of an AU member country are immune from prosecution during their terms in office. ${ }^{147}$ This provision creates a sharp divergence from other international criminal tribunals, including the ICC, whose constitutive documents provide that sitting heads of state are not immune from prosecution. ${ }^{148}$

Commentators had different responses to the Head of State immunity amendment to the ACJHR Protocol. Some emphasized that because that regional court's jurisdiction would not be retrospective, it posed little threat to the prosecutions of Kenyatta and Ruto in the Hague. ${ }^{149}$ Others expressed concern about what cases, if any, would fall within the ICC's jurisdiction once the ACJHR was operational, speculating that the immunity amendment would herald the demise of the ICC's role in Africa. ${ }^{150}$ Given the lack of any immediate impact on the prosecutions in the Hague, the proposal's aim was likely as much political as legal — to fuel opposition to the ICC support for alternative venues for prosecuting international crimes that would not infringe the sovereignty of African nations. ${ }^{151}$

\footnotetext{
145 du Plessis, supra note 142, at 1.

${ }^{146}$ Monica Mark, African Leaders Vote Themselves Immunity from New Human Rights Court, THE GUARDIAN (July 3 , 2014), http://goo.gl/rxJWfU.

${ }^{147}$ African Union, Twenty-Fifth Ordinary Session, June 20-24, 2014, The Draft Legal Instruments and Recommendations of the Specialized Technical Committee on Justice and Legal Affairs, EX.CL/846(XXV), http://justsecurity.org/wp-content/uploads/2014/07/Legal-Instruments-Adopted-in-Malabo-July-2014.pdf. The amendment provides: "No charges shall be commenced or continued before the Court against any serving African Union Head of State or Government, or anybody acting or entitled to act in such capacity, or other senior state officials based on their functions, during their tenure of office."

${ }^{148}$ Beth Van Schaack, Immunity Before the African Court of Justice \& Human \& Peoples Rights-The Potential Outlier, JUST SECURITY (July 10, 2014), https://goo.gl/7PJe1c. The East African Community (EAC) also considered the possibility of regional prosecutions. On April 26, 2012, the East African Legislative Assembly endorsed a motion to transfer the Kenyan cases to the East African Court of Justice ("EACJ"). To enable the transfer, the EAC resolved to extend the mandate of the EACJ to include prosecutions of crimes against humanity. Kenya: Rights Groups Oppose Move to Sideline ICC, IRIN (May 2, 2012), http://goo.gl/Hdwen8.

149 du Plessis, supra note 142 , at 11.

${ }^{150}$ Stephane Mader, Unjust African Justice, OPINION INTERNATIONALE (Sept. 12, 2014), https://goo.gl/bGYHsw.

151 Thomas Obel Hanson, Master of Manipulation: How the Kenyan Government is Paving the Way for Non-

Cooperation with the ICC, OPEN SECURITY (May 30, 2012), https://goo.gl/KEpJA0.
} 


\section{F. Proposals to Amend the Rome Statute}

Kenya proposed several amendments to the Rome Statute to be considered at the Twelfth Session of the ICC Assembly of States Parties in November 2013. ${ }^{152}$ The proposals addressed a variety of issues related to the State's objection to the Hague prosecutions of Kenyatta and Rutoexpanding the reference to complementarity in the Rome Statute's Preamble to cover regional courts; granting immunity for Heads of State under Article 27 of the Statute; excusing defendants from presence at trial under Article 63; and establishing an Independent Oversight Mechanism pursuant to Article 112 to deal with offenses committed under Article 70.

By following the Rome Statute's formal amendment procedures, Kenya appeared to be acting cooperatively within the ICC framework. However, because the amendments were not submitted with the three months' notice required by Article 121 of the Rome Statute, they could not be adopted at the November 2013 meeting. ${ }^{153}$ Thus, while the amendments were discussed, they were not subject to the same level of scrutiny as amendments that could have been adopted at that session. Notwithstanding this procedural defect, the amendments generated political pressure for reforms to narrow the ICC's ability to prosecute high-level political leaders. The amendments were discussed again at the Thirteenth Session in December 2014, but the report noted without explanation the "agreement that further discussions would be necessary." 154 It seems that only the amendment regarding the IOM was discussed again at the Fourteenth Session, where a resolution was adopted to broaden the IOM's authority. ${ }^{155}$

\footnotetext{
${ }^{152}$ Decision on Africa's Relationship with the International Criminal Court (ICC), supra note 74, at 10 (vii).

${ }^{153}$ Coalition for the International Criminal Court, Report on the $12^{\text {th }}$ Session of the Assembly of States Parties to the Rome Statute (Nov. 20-28, 2013) [hereinafter $12^{\text {th }}$ Session Report], http://goo.gl/yeOe1O.

${ }^{154}$ Assembly of States Parties, Thirteenth Session, Report of the Working Group on Amendments, ICC-ASP13/31, 7 (Dec. 8-17, 2014), https://asp.icc-cpi.int/iccdocs/asp_docs/ASP13/ICC-ASP-13-31-ENG.pdf.

${ }_{155}$ Assembly of States Parties, Fourteenth Session, Advance Version: Official Records (Nov. 18-26, 2015), https://www.icc-cpi.int/RelatedRecords/CR2015_25102.PDF.
} 


\section{Complementarity}

Kenya's proposed amendment to the Rome Statute's Preamble would expand the doctrine of complementarity to include regional investigation and prosecution mechanisms. ${ }^{156}$ It reads: "Emphasizing that the International Criminal Court established under this Statute shall be complementary to national and regional criminal jurisdictions." Presently, the Preamble only discusses complementarity in the context of national courts. If adopted, the amendment would provide a basis for ICC opponents to challenge future decisions by the Prosecutor not to defer to African regional courts whose jurisdiction includes international crimes.

\section{Administration of Justice and Independent Oversight Mechanism}

Article 70 of the Rome Statute gives the ICC jurisdiction over intentional offenses against the administration of justice including: giving false testimony under oath; presenting evidence that a party knows is forged; interfering with witnesses; intimidating or corruptly influencing a court official and retaliating against an official of the Court. The proposed amendment would clarify that these offenses can be committed not only by defendants, witnesses, and attorneys but also by Court officials. ${ }^{157}$ In support of this amendment, Kenya cited "the current situation in the Kenyan cases, especially Trial Chamber V(b)." This appears to be a reference to the ICC Prosecutor's allegations that Kenyan officials interfered with prosecution witnesses (discussed in subsection $\mathrm{H}$ below), which defense counsel challenged as both false and illustrative of pro-prosecution bias of Article $70 .{ }^{158}$

Kenya proposed another amendment that took aim at the prosecution—expanding the powers of the Independent Oversight Mechanism ("IOM"). ${ }^{159}$ The IOM was created in 2009 pursuant to

\footnotetext{
${ }^{156}$ Assembly of States Parties, Thirteenth Session, Report of the Working Group on Amendments, ICC-ASP13/31, ๆ 15 (Dec. 8-17, 2014), https://asp.icc-cpi.int/iccdocs/asp_docs/ASP13/ICC-ASP-13-31-ENG.pdf.

${ }^{157} \mathrm{Id}$. at 16.

${ }^{158}$ Mark Kersten, Kenyatta's Next Move: What Kenya Wants from the ICC, JUSTICE IN CONFLICT (Nov. 13, 2013), http://justiceinconflict.org/2013/11/13/kenyattas-next-move-what-kenya-wants-from-the-icc/.

${ }^{159}$ Report of the Working Group on Amendments, supra note 154, at 16.
} 
Article 112(4) of the Rome Statute with a narrow mandate - to investigate misconduct by staff, elected officials, and contractors. ${ }^{160}$ Kenya proposed that the IOM be given broader powers- to investigate and inspect all organs of the Court, including the Office of the Prosecutor. ${ }^{161}$ The government emphasized that the Office is not currently subject to sufficient oversight because it "has power to act independently and as a separate organ of the court with full authority over [its own] management and administration ...."162 At its Fourteenth Session, the ASP adopted a resolution broadening the IOM's authority. ${ }^{163}$ The resolution provides that the IOM may "receive and investigate reports of misconduct or serious misconduct, including possible unlawful acts by ... the Prosecutor" and sets out a detailed procedure for conducting such investigations. ${ }^{164}$

\section{Head of State Immunity}

Kenya's proposal to make Heads of State immune from prosecution during their terms in office has its origins in an AU proposal to exempt sitting Heads of State from prosecutions for international crimes. In January 2012, the AU decided to seek an advisory opinion from the International Court of Justice on the immunity of state officials under international law. ${ }^{165}$ This avenue was never pursued. Instead, at the Extraordinary Summit in October 2013, the AU decided that heads of state were immune from prosecution during their terms of office, citing national law

\footnotetext{
${ }^{160}$ Assembly of States Parties, Establishment of an Independent Oversight Mechanism, ICC-ASP/8/RES-1 ๆ 6(c) (Nov, 26, 2009), http://iccforum.com/media/background/oversight/2009-11-26 Resolution ICC-ASP-8-Res.1 (English).pdf. The resolution establishing the IOM explained that "additional elements of oversight . . . such as inspection and evaluation" would be addressed at a later date. $I d$. at 9 6(a).

${ }^{161}$ Report of the Working Group on Amendments, supra note 154, at 16.

${ }^{162} I d$. at 16 (emphasis omitted).

${ }^{163}$ See generally Assembly of States Parties, Resolution on the Independent Oversight Mechanism, ICC-ASP/12/RES. 6, https://asp.icc-cpi.int/iccdocs/asp docs/Publications/Compendium/Resolution-IOM-ENG.pdf.

164 Id. at 28.

${ }^{165}$ African Union, Eighteenth Ordinary Session, Jan. 29-30, 2014, Decision on the Progress Report of the Commission on the Implementation of the Assembly Decisions on the International Criminal Court, in Decisions, Resolution, and Declarations, Assembly/AU/Dec. 391-415(XVII), http://goo.gl/rg3ZHi.
} 
and international customary law. ${ }^{166}$ The AU also decided that states parties should "propose relevant amendments to the Rome Statute" to give effect to this immunity. ${ }^{167}$

At the Twelfth Session of the ASP, Kenya proposed an amendment to Article 27 of the Rome Statute. ${ }^{168}$ As written, Article 27 emphasizes that official capacity neither exempts an individual from criminal responsibility nor serves as a valid basis for a reduced sentence. ${ }^{169}$ The amendment would preclude prosecutions of serving heads of state, their deputies and anyone acting or entitled to act in such a capacity. The AU requested a special session of the ASP to discuss the proposal. ${ }^{170}$ The session produced heated debates, especially in the wake of the Security Council's rejection of Kenya's deferral request a few days earlier. ${ }^{171}$

At the Thirteenth Session of the ASP in December 2014, Kenya clarified that the proposal's objective was not intended to definitively grant immunity to Heads of State, but rather to "pause" prosecution during a political leader's term in office. ${ }^{172}$ However, several delegations were concerned about the proposal's lack of precision and others were categorically opposed to modifying what they considered a "cornerstone" of the Rome Statute. The proposal was not discussed at the Fourteenth Session, although it may be discussed at a future meeting of the ASP.

G. Lobbying to Avoid Requiring the Accused's Presence at Trial

\footnotetext{
${ }^{166}$ Decision on Africa's Relationship with the International Criminal Court, supra note 74.

${ }^{167} \mathrm{Id}$. at 10 (vi).

${ }^{168}$ Kenya: Proposal of Amendments to the Rome Statute of the International Criminal Court, Reference: C.N.1026.2013.TREATIES-XVIII.10 (Mar. 14, 2014) [hereinafter Kenya Proposed Amendments], https://reaties.un.org/doc/Publication/CN/2013/CN.1026.2013-Eng.pdf. This document reflects that the UN SecretaryGeneral received Kenya's proposals on November 22, 2013. The proposals were then discussed at the 12th Session of the ASP, help on November 20-28 of 2013. The document is dated March 14, 2014, because that is the date on which the proposals were officially deposited with the UN.

${ }^{169}$ Kenya Proposed Amendments, supra note 168.

${ }^{170}$ Assembly of States Parties, Twelfth Session, Special Segment as Requested by the African Union: Indictment of Sitting Heads of State and Government and its Consequences on Peace and Stability and Reconciliation, ICCASP/12/61, http://www.icc-cpi.int/iccdocs/asp docs/ASP12/ICC-ASP-12-61-ENG.pdf.

${ }^{171}$ Week of Setbacks for Kenya at the Hague, DAILY NATION (November 23, 2013), http://goo.gl/SfVptH.

${ }^{172}$ Report of the Working Group on Amendments, supra note 154, at 12.
} 
Kenyatta and Ruto worked both within and outside of the Rome Statute framework to avoid appearing in-person at proceedings in the Hague. Within the framework, Kenya proposed amendments to the Rome Statute and to the Rules of Procedure to allow for remote appearances. Outside of the framework, the defendants made comments conditioning their cooperation upon the Court's agreeing to procedures to enable them to carry out their official duties.

Although during the election campaigns Kenyatta and Ruto maintained that their trials were a personal matter, their narrative shifted after their victory. ${ }^{173}$ As Kenyatta warned the ICC in a statement made after the election: "I speak not as an accused person, but as the President of the sovereign Republic of Kenya. . . If you want us to continue to cooperate let me make it clear that when Ruto is in the Hague I will be here, and when I am in the Hague, Ruto will be here." Kenyatta later temporarily stepped down from office to participate in a hearing in his case.

Defense counsel for both Kenyatta and Ruto requested that both leaders be excused from continuously attending their trials. In decisions issued in June $2013^{174}$ and October $2013,{ }^{175}$ these requests were conditionally granted by the respective ICC Trial Chambers. Commentators criticized the legal basis of Trial Chamber V(a)'s initial decision excusing Ruto, which emphasized his constitutional duties as Deputy President in language reminiscent of the AU's letter and thus could be seen as a partial recognition of immunity for a sitting head of state. ${ }^{176}$

Commentators have speculated that the ICC rulings were influenced by the officials' assertions that the trials would disrupt their governmental duties, which, in turn, gave the impression

\footnotetext{
${ }^{173}$ Wanjohi Kabukuru, No Longer Vague, it is the Hague, AFRICAN BUSINESS (Sept. 2013), http://africanbusinessmagazine.com/africa-within/countryfiles/no-longer-vague-it-is-the-hague/. ${ }^{174}$ Prosecutor v. William Samoei Ruto and Joshua Arap Sang, Decision on Mr. Ruto's Request for Excusal from Continuous Presence at Trial, ICC-01/09-01/11 (June 18, 2013), https://www.icccpi.int/CourtRecords/CR2013_04536.PDF.

${ }^{175}$ Prosecutor v. Uhuru Muigai Kenyatta, Decision on Defense Request for Conditional Excusal from Continuous Presence at Trial, ICC-01/09-02/11(Oct. 18, 2013), https://www.icc-cpi.int/CourtRecords/CR2013_07592.PDF. ${ }^{176}$ Thomas Obel Hansen, The Price of Deference: Is the ICC Bowing to Pressure in the Kenya Cases?, JUSTICE IN Conflict (Nov. 16, 2013), https://goo.gl/EurZqj.
} 
that the judges could be politically manipulated. ${ }^{177}$ For instance, the Trial Chamber initially rejected Ruto's request for alternating trials, which would have allowed either Kenyatta or Ruto to be present in Kenya at all times. However, during a status conference one day before the trials were scheduled to begin, the judge presiding over Trial Chamber V(a) announced that he preferred to try the cases in four week alternating blocks because "running the cases simultaneously will not necessarily expedite them." ${ }^{178}$ This announcement came one day after Kenyatta conditioned cooperation with the ICC on the requirement that he and Ruto not be required to attend trials at The Hague simultaneously.

On July 29, 2013 the Prosecutor filed an appeal in the Ruto case. Several African states, including Tanzania, Rwanda, Eritrea, Uganda and Burundi, sought leave to file amicus curiae briefs supporting Ruto's excusal under Rule 103(1) of the Rules of Procedure and Evidence. ${ }^{179}$ Commentators speculated that the Appeals Chamber order granting these countries permission to file amicus briefs was influenced by the Kenyan Attorney General's statement that "the ICC gives more hearing to civil society than it does to State Parties." 180 The governments' briefs included extrajudicial statements supporting Kenyan's position. Rwanda, for example, suggested that it would refuse to join the ICC if the issue was not resolved in the defendant's favor. ${ }^{181}$ Regardless, the Appeals Chamber unanimously reversed the Trial Chamber's decision on October 25, 2013. ${ }^{182}$ The Appeals Chamber concluded that by providing Ruto with "a blanket excusal" before the trial even commenced, "making his absence the general rule and his presence the exception," the Trial Chamber abused its discretion. ${ }^{183}$

\footnotetext{
${ }^{177} I d$.

${ }^{178} \mathrm{Id}$.

${ }^{179} I d$.

${ }^{180} \mathrm{Id}$.

${ }^{181} \mathrm{Id}$.

${ }^{182}$ Prosecutor v. William Samoei Ruto and Joshua Arap Sang, Judgment on the Appeal of the Prosecutor Against the Decision of Trial Chamber V(a) of 18 June 2013 entitled “Decision on Mr. Ruto's Request for Excusal from Continuous Presence at Trial, “ ICC-01/09-01/11 OA 5 - 2 (Oct. 25 2013), https://www.icccpi.int/CourtRecords/CR2013_07731.PDF.

${ }^{183} I d$. at 93.
} 
In a September 2013 letter, the AU criticized the Appeals Chamber's ruling. ${ }^{184}$ The letter emphasized that the defendant's inability to participate in crucial diplomatic events would hinder peace, security and stability, both nationally and regionally. The letter also portrayed the Appeals Chamber's decision as inconsistent with a proper consideration of Ruto's constitutional responsibilities. The AU later encouraged Kenya to propose amendments to the Rome Statute and the Rules of Procedure and Evidence to facilitate excusing defendants who are sitting government officials.

Kenya proposed a pair of amendments shortly thereafter. The first was to Article 63(2) of the Rome Statute. Article 63(2) provides for trial in the absence of the accused in exceptional circumstances without elaborating on what qualifies as an exceptional circumstance. The amendment provides that "an accused may be excused from continuous presence in the Court after the Chamber satisfies itself that exceptional circumstances exist, alternative measures have been put in place and considered, including but not limited to changes to the trial schedule or temporary adjournment or attendance through the use of communications technology or through representation of counsel." The provision then states that "[a]ny such absence shall be considered on a case-by-case basis and be limited to that which is strictly necessary." 185

Kenya also proposed an amendment to Rule 134 of the Rules of Procedure and Evidence to excuse heads of state from being personally present at trial. ${ }^{186}$ Unlike an amendment to the Rome Statute, such an amendment could take effect immediately. The Twelfth Session of the Assembly of States Parties adopted by consensus Rule 134quater, which provides that "an accused subject to a summons to appear who is mandated to fulfill extraordinary public duties at the highest national level

\footnotetext{
${ }^{184}$ African Union Letter to the President of the International Criminal Court, BC/U/1657.09.13 (Sept. 2013) http://www.icc-cpi.int/en menus/icc/press\%20and\%20media/press\%20releases/Documents/pr943/130910-AU-letter-toSHS.pdf.

${ }_{185}^{185}$ Kenya Proposed Amendments, supra note 168.

${ }^{186} 12^{\text {th }}$ Session Report, supra note 153.
} 
may submit a written request to the Trial Chamber to be excused and to be represented by counsel only." ${ }^{187}$ Pursuant to Rule 134quater, Ruto submitted an new excusal request. ${ }^{188}$ The Trial Chamber V(a) conditionally granted the request, requiring Ruto to be present only at specific hearings. ${ }^{189}$ It also denied the Prosecutor's application for leave to appeal. ${ }^{190}$

Kenyatta followed a different approach, invoking Article 143(7) of the Kenyan Constitution to temporarily step down in favor of Ruto as acting President the country-the first time that this provision of the Constitution had ever been invoked. ${ }^{191}$ Explaining his decision, Kenyatta stated: "Nothing in my position or my deeds as President warrants my being in court... Therefore, let it not be said that I am attending the status conference as the President of Kenya." ${ }^{192}$ Kenyatta also reasserted his view that the trials were an affront to the nation's sovereignty: "I chose not to put the sovereignty of more than 40 million Kenyans on trial since their democratic will should never be subject to another jurisdiction.",193

\section{H. Non-Cooperation with the Office of the Prosecutor}

Throughout the cases, the Prosecutor criticized the Kenyan government for recalcitrance in handing over evidence and facilitating access to critical witnesses. ${ }^{194}$ That non-cooperation

\footnotetext{
${ }^{187}$ Assembly of States Parties, Amendments to the Rules of Procedure and Evidence, ICC-ASP/12/Res.7, 3 (Nov. 27, 2013), https://asp.icc-cpi.int/iccdocs/asp_docs/Resolutions/ASP12/ICC-ASP-12-Res7-ENG.pdf; $12^{\text {th }}$ Session Report, supra note 153 , at 20.

${ }^{188}$ Prosecutor v. William Samoei Ruto and Joshua Arap Sang, Defense Request Pursuant to Article 63(1) of the Rome Statute and Rule 134quater of the Rules of Procedure and Evidence to Excuse Mr. William Samoei Ruto from Attendance at Trial, ICC-01/09-01/11 (Dec. 16, 2013) https://www.icc-cpi.int/CourtRecords/CR2013_10668.PDF. ${ }^{189}$ Prosecutor v. William Samoei Ruto and Joshua Arap Sang, Reasons for the Decision on Excusal from Presence at Trial under Rule 134quater, 1CC-01/09-01/11 (Feb. 18, 2014), http://goo.gl/SSJWdL.

${ }^{190}$ Prosecutor v. William Samoei Ruto and Joshua Arap Sang, Decision on Prosecutor's Application for Leave to Appeal the Decision on Excusal from Presence at Trial under Rule 134quater, ICC-01/09-01/11 (April 2, 2014) at https://www.icc-cpi.int/CourtRecords/CR2014_03183.PDF.

${ }^{191}$ Beth Van Schaack, Two Tales of a Hearing, Kenyatta and the Court, JUST SECURITY (Oct. 10, 2014), http://justsecurity.org/16199/tales-hearing-kenyatta-court/.

${ }^{192}$ Kenya President Steps Down for ICC Hearing, SKYNEws (Oct. 6, 2014), http://news.sky.com/story/1348355/kenyapresident-steps-down-for-icc-hearing.

${ }^{193} I d$.

${ }^{194}$ Office of the Prosecutor, Statement by the Prosecutor on the Decision to Withdraw Charges Against Mr. Muthuara, International Criminal Court (March 11, 2013), https://goo.gl/ScWzLb.
} 
contributed to delays in the proceedings and, eventually, to the dismissal of the cases against Kenyatta and Muthuara-decisions that news reports described as "an unprecedented admission of failure by Prosecutors."

In Kenyatta's case, the Prosecutor sought a finding of noncompliance against the government based on its failure to respond to requests for financial and other records. ${ }^{196}$ The Attorney General responded that a ruling by Kenyan courts was required to compel the government to hand over the requested documents. ${ }^{197}$ The Trial Chamber disagreed, ruling that: "Any purported deficiency in domestic legal procedures cannot be raised . . . as a shield to protect a state party from its obligation to cooperate with the court ...."198 It also noted "at the very least, the possibility of a potential conflict of interests in this case" regarding the duty of persons or organs acting on the State's behalf to comply with the requests. Although the Trial Chamber did not make a formal finding of noncompliance, it noted that the government had "unjustifiably frustrated" the investigation. ${ }^{199}$

In an attempt to strengthen its case against the defendants, the Prosecution procured a summons from the Trial Chamber ordering the Kenyan government to employ "all means available under the law of Kenya" to bring eight witnesses before the Court. ${ }^{200}$ The Court also signaled that it would not tolerate attempts to undermine the Prosecutor's investigation. For example, in 2013 the ICC unsealed an arrest warrant for Walter Barasa, who had allegedly corrupted ICC witnesses. ${ }^{201}$

\footnotetext{
${ }^{195}$ ICC Prosecutors Drop Case Against Kenyan Politician Francis Muthuara, THE GUARDIAN (March 11, 2013), http://www.theguardian.com/law/2013/mar/11/icc-prosecutors-kenyan-francis-muthaura.

${ }^{196}$ Prosecutor v. Uhuru Muigai Kenyatta, Decisions on the Prosecutions Applications for a Finding of Non-Compliance Pursuant to Article 87(7) and for an Adjournment of the Provisional Trial Date, ICC-01/09-02/11-908, (March 31, 2014), http://www.icc-cpi.int/iccdocs/doc/doc1755190.pdf.

${ }^{197}$ Tom Maliti, Kenya's Attorney General Says a Court Order is Needed to Get Kenyatta Financial Records, International Justice Monitor (Feb. 13, 2014), http://goo.gl/TDVWvN.

${ }^{198}$ Decisions on the Prosecutions Applications for a finding of Non-Compliance Pursuant to Article 87(7) and for an Adjournment of the Provisional Trial Date, supra note 196, at 97.

${ }^{199}$ J.J. Wangui, Kenyan President's Trial Adjourned until October, Institute for War \& PeAce Reporting (April 1, 2014), http://iwpr.net/report-news/kenyan-presidents-trial-adjourned-until-october.

${ }^{200}$ ICC Summons Witnesses for Prosecution in Ruto Case, Institute for War and Peace Reporting (April 23, 2014), http://iwpr.net/report-news/icc-summons-witnesses-prosecution-ruto-case.

${ }^{201}$ Prosecutor v. Walter Osapiri Barasa, Warrant of Arrest for Walter Osapiri Barasa, ICC-01/09-01/13-1-Red2 (Sept. 26, 2013), http://www.icc-cpi.int/iccdocs/doc/doc1650592.pdf. Commentators speculated that Barasa worked in conjunction with the government, given that the Kenyan Court of Appeals issued an order blocking his arrest. Tom
} 
Kenya's response was recalcitrance. In a written submission on May 10, 2013, the Prosecutor informed the ICC of "reports received from prosecution witnesses that they have been targeted by [government] officials seeking to influence their testimony," adding that "[s]ome public officials in Kenya have fostered an anti-ICC climate in Kenya . . .."202 The Prosecutor cited this climate when discussing the "unprecedented level of witness interference" that plagued the investigations. In the absence of reliable witness testimony, the Prosecutor was forced to concede that there was insufficient evidence to try President Kenyatta. Ultimately, the case was dismissed due to a lack of evidence. ${ }^{203}$

The dismissal cannot, however, be entirely attributed to Kenya's refusal to turn over documents and its alleged interference with witnesses. Commentators have noted that some evidentiary gaps may be attributed to the Prosecutor's early mishandling of the case, ${ }^{204}$ and the Trial Chamber itself expressed "serious concerns" about the "timeliness and thoroughness" of the Prosecutor's work. Some of the government's recalcitrance may also be attributed to ordinary pretrial tactics. However, the Kenyan government deployed these tactics at least in part to tarnish the public perception of the ICC. For example, Attorney General Githu Muigai criticized the Prosecutor for requesting a delay to gather evidence in Kenyatta's case. "Where did the evidence go?" he asked when adamantly asserting that if such critical evidence were absent the Court should never have confirmed the proceedings. ${ }^{205}$

That criticism added to the ICC's image crisis in Kenya. A sampling of local headlines included the titles: "Githu Muigai Rocks the ICC as he Teaches Bensouda and ICC Judges Some

\footnotetext{
Maliti, Kenyan Court of Appeals Suspends Warrant Against Barasa, InTERnATIONAL JustiCE Monitor (May 29, 2014), http://www.ijmonitor.org/2014/05/kenyan-court-of-appeal-suspends-arrest-warrant-against-barasa/.

${ }^{202}$ Bernard Momanyi, Kenya Witnesses Face Harassment, InstituTE FOR WAR \& PEACE REPORTING (June 5, 2013) at http://iwpr.net/report-news/kenya-witnesses-face-harassment.

${ }^{203}$ Office of the Prosecutor, Statement by the Prosecutor of the International Criminal Court, Fatou Bensouda, on the Withdrawal of Charges Against Mr. Uhuru Muigai Kenyatta (May 2014), http://www.icccpi.int/en menus/icc/press\%20and\%20media/press\%20releases/pages/otp-statement-05-12-2014-2.aspx.

${ }^{204}$ Elizabeth Evenson, Justice for Kenya Stumbles at the ICC, Policy Review (December 2013), http://www.policyreview.eu/justice-for-kenya-stumbles-at-the-icc/.

${ }^{205}$ Mwakilishi, Kenyan Attorney General Githu Muigai Slams ICC Over Cooperation, (May 24, 2013), http://goo.gl/fmo2ku.
} 
Law" ${ }^{206}$ As previously noted, the public initially voiced strong support for trying the defendants in The Hague. ${ }^{207}$ Opinion polls indicated that the central reasons for early public support for the Hague proceedings were the belief that the trials would end impunity and that the national judiciary was illequipped to handle the cases. ${ }^{208}$ However, as the cases progressed, public support declined. ${ }^{209}$ Commentators traced this decline to two factors linked to the government's recalcitrance- the Prosecutor's decision to drop the charges against Francis Muthuara, and the seemingly perpetual delay of the trials. ${ }^{210}$

\section{Rhetoric Politicizing the ICC Trials}

As previously explained, Ruto and Kenyatta's 2013 election campaign invoked the ICC prosecutions for political gain, using ethnic and political rhetoric to chill domestic support for the prosecutions. Although most references to the ICC were oblique, and Kenyatta and Ruto professed their intention to cooperate fully with the Court, their campaign rhetoric was replete with language of anti-colonialism and self-determination that helped to fuel later opposition to the prosecutions. ${ }^{211}$ For example, leaders cited comments by the U.S. Ambassador that the election of the indicted Kenyatta would have "consequences" as an illustration of Western manipulation. The campaigns also highlighted statements by United Kingdom diplomats warning that if Kenyatta were elected, that the

\footnotetext{
${ }^{206}$ Githu Muigai Rocks the ICC as he Teaches Bensouda and ICC Judges Some Law, THE DAILY POST (Oct. 2014), http://www.kenyan-post.com/2014/10/githu-muigai-rocks-icc-as-he-teaches.html.

${ }^{207}$ Review Report, supra note 27, at 12.

${ }^{208}$ The ICC Issue and Raila's Political Future, supra note 36.

${ }^{209}$ Felix Olick, Kenyan Support for ICC Trials Falls, InSTITUTE FOR WAR \& PEACE REPORTING (Aug.25, 2013), http://iwpr.net/report-news/kenyan-support-icc-trials-falls.

${ }^{210}$ Olick, supra note 36.

${ }^{211}$ Perry, supra note 28. See also Robert Wanjala, Acting Out Justice for Kenya, InSTITUTE FOR WAR \& PEACE REPORTING (Feb. 25, 2013), http://iwpr.net/report-news/acting-out-justice-kenya.
} 
U.K, country would minimize diplomatic contact with Kenya. ${ }^{212}$ The candidates also framed the prosecutions as Western indictments of Kenyatta and Ruto's respective ethnic communities. ${ }^{213}$

Kenyatta's nationalist rhetoric against the ICC increased after he assumed the Presidency. The keynote speaker at the inauguration congratulated the Kenyan people for rejecting the "blackmail of the ICC," alleging that Western governments were using the Court to "install leaders of their choice in Africa and eliminate the ones they do not like." ${ }^{214}$ Kenyatta's presidential speech was more equivocal, asserting that the defendants would comply with the ICC but also that they expected the Court to "respect our sovereignty." ${ }^{215}$ The anti-ICC rhetoric intensified in the weeks leading up to Kenyatta's October 2014 hearing at the Hague, which Kenyatta attended in his private capacity to avoid putting "the sovereignty of more than forty million Kenyans on trial."216

\section{Three Overarching Themes of the Kenyan Backlash against the ICC}

The narratives above illustrate the different ways in which the Kenyan government expressed its strident opposition to the prosecutions of Kenyatta and Ruto, undermining the legal and political legitimacy of the ICC in Kenya, among other African states, and in the African Union. When viewed together, these discrete instances of opposition amount to an integrated strategy of backlash against the Court that is characterized by several unifying themes. This Part explains these themes and explores their legal and political consequences.

\footnotetext{
${ }^{212}$ Perry, supra note 28. See also Lordrick Mayabi, What Consequences? Ask Uhuru, Ruto, CAPITAL News (Feb. 9 2013), http://www.capitalfm.co.ke/news/2013/02/what-consequences-ask-uhuru-ruto/?wpmp switcher=mobile. ${ }^{213}$ Gabrielle Lynch and Misa Zgonec-Rozej, The ICC Intervention in Kenya, Chatham House, 10-11 (Feb. 2013) http://www.chathamhouse.org/sites/files/chathamhouse/public/Research/Africa/0213pp icc kenya.pdf. Speeches politicizing the trials also preceded the defendants' campaign. For example, during Ruto's hearing in April 2011, Trial Chamber II warned the suspects that using "dangerous speeches" would lead to arrest warrants. Maurice Dunanski, Accountability v. Stability? Assessing the ICC's Intervention in Kenya, E-International Relations Students (Jan. 2014), http://www.e-ir.info/2014/01/09/accountability-vs-stability-assessing-the-iccsintervention-in-kenya/.

${ }^{214}$ Luke Obala, Kenya's 2013 Elections and Emerging Foreign Policy, AlJazeera Center for Studies (June 6, 2013) http://studies.aljazeera.net/en/reports/2013/06/2013668593465518.htm. ${ }^{215}$ The Big Read: Rhetoric and Reality, THE TIMES LIVE (April 8, 2014), http://www.timeslive.co.za/opinion/commentary/2013/04/08/the-big-read-rhetoric-and-reality.

${ }^{216}$ Kenya: Ruto the Acting President as I Attend ICC Case, All AfriCA (Oct. 6, 2014), http://allafrica.com/stories/201410062000.html.
} 


\section{A. Cloaking Sovereignty Claims in Arguments about Complementarity}

In lobbying the AU for support of an Article 16 deferral of the prosecutions, and in requesting such a deferral from the UN Security Council, Kenya capitalized on a tension at the heart of the Rome Statute - the careful compromise between international criminal justice and state sovereignty. ${ }^{217}$ Specifically, the government strategically manipulated the key legal concept that embodies that delicate balance-the principle of complementarity. ${ }^{218}$ Government officials repeatedly employed complementarity to frame the ICC trials as an affront to Kenyan sovereignty. This section illustrates the government's efforts to link complementarity and sovereignty in three ways: (1) politicizing complementarity, (2) eliding positive and negative complementarity, and (3) raising complementarity arguments that are not legally viable.

\section{Politicizing Complementarity}

As previously discussed, the National Assembly never adopted a bill to create a Special Tribunal for Kenya. ${ }^{219}$ This did not, however, deter the Kenyan government from raising complementarity arguments once it became clear that the ICC prosecutions would proceed. One such argument featured prominently in the Assembly's 2010 motion to withdraw from the Rome Statute. Expressly citing complementarity, the motion resolved that "any further criminal investigations or prosecutions arising out of the post-election violence" should be undertaken at the national level in light of the new Kenyan Constitution promulgated in 2010. The 2010 Constitution included reforms aimed at improving judicial independence and competence, ${ }^{220}$ which the Assembly asserted as a

\footnotetext{
${ }^{217}$ Chandra Lekham Sriram and Stephen Brown, Kenya in the Shadow of the ICC: Complementarity, Gravity and Impact, 12 INT'L CRIM. L. REV. 1, 219-44 (2012), http://goo.gl/bfJHjf.

${ }^{218}$ See Rome Statute, supra note 87 , pmbl. (the ICC "shall be complementary to national criminal jurisdictions").

${ }^{219}$ How Kenya Handled Local Tribunal Process, supra note 22.

${ }^{220}$ Migai Akech, Institutional Reform in the New Constitution of Kenya, International Center for Transitional Justice 28-29 (October 2010), http://ictj.org/sites/default/files/ICTJ-Kenya-Institutional-Reform-2010-English.pdf.
} 
fundamental change in circumstances justifying the ICC to step back from its prosecutions of Kenyatta and Ruto. ${ }^{221}$

Debate in the National Assembly over the unanimously-adopted motion suggests that the invocation of complementarity was part of a broader political strategy. By linking complementarity to respect for sovereignty, the government situated the withdrawal motion within a larger narrative framing the prosecutions as a Western effort to manipulate Kenyan domestic politics. ${ }^{222}$ For example, the Energy Minister remarked: "It is only Africans from former colonies who are being tried at the ICC ... . No British or American will be tried at the ICC and we should not willingly allow ourselves to return to colonialism."223 The 2010 motion thus implied that the ICC's "failure" to transfer the cases to a domestic or regional forum was evidence that the Court was carrying out the will of Western governments.

\section{Eliding Positive and Negative Complementarity}

Literature on the Rome Statute distinguishes between two types of complementarity: negative and positive. Negative complementarity reflects the principle that the ICC should not investigate or prosecute international crimes where a state with jurisdiction over such crimes is able and willing to do so. Positive complementarity, on the other hand, refers to the ICC's affirmative duty to promote national trials by taking measures including, but not limited to, directly assisting national prosecutions through the transfer of evidence, establishing training programs for police and national prosecutors, and encouraging specific states to investigate particular crimes. ${ }^{224}$

\footnotetext{
2212010 Motion, supra note 91.

${ }^{222}$ Kenya MP's Vote to Leave ICC Over Poll Violence Claims, BBC: NEws AFRICA (Dec. 23, 2010), http://www.bbc.com/news/world-africa-12066667.

${ }^{223} I d$.

${ }^{224}$ Carsten Stahn and Mohamed M. El Zeidy, ThE InTERnATIONAL CRIMINAL COURT AND COMPLEMENTARITY: From THEORY TO PRACTICE (2011); see also Lionel Nichols, THE INTERNATIONAL CRIMINAL COURT AND THE END OF IMPUNITY IN KENYA 29-38 (2015) (discussing positive complementarity).
} 
The Rome Statute's admissibility standards expressly incorporate negative complementarity. Under Article 17(1)(a), for example, the ICC cannot take cognizance of a case if a State with jurisdiction is conducting an investigation, "unless the State is unwilling or genuinely unable to carry out the investigation or prosecution." 225 In contrast, no provision of the Rome Statute expressly recognizes the positive complementarity principle.

The first ICC Chief Prosecutor nevertheless interpreted the principle as a tool for promoting national criminal proceedings. ${ }^{226}$ During a 2004 strategy discussion, for example, Luis MorenoOcampo stated that the Office of the Prosecutor would take "a positive approach to complementarity. Rather than competing with national systems for jurisdiction, we will encourage national proceedings wherever possible." ${ }^{227}$ Although the Prosecutor's early interpretation of the Rome Statute suggested that ICC would facilitate domestic prosecutions, such an approach has not been followed in cases referred to the Court. ${ }^{228}$

Although the two types of complementarity are distinct conceptually, in terms of their legal foundations, and in the actions they require of ICC officials, the Kenyan government intentionally elided these distinctions and portrayed positive complementarity as part of the ICC's affirmative mandate. This strategy enabled the government to dexterously deflect attention away from the absence of domestic investigations of Kenyatta and Ruto (as opposed to investigations of the postelection violence in general) and to frame the ICC's failure to employ positive complementarity as proof that international prosecutions showed a lack of respect for Kenyan sovereignty.

The government's demand that the ICC defer to a national or regional alternative to prosecutions in the Hague are among the clearest illustrations of this conceptual slight-of-hand. In

\footnotetext{
${ }^{225}$ See Rome Statute, supra note 87, art. 17(1)(a).

${ }^{226}$ William W. Burke-White, Proactive Complementarity: The International Criminal

Court and National Courts in the Rome System of International Justice, 49 HARV. INT. L.J. 53,55 (2008).

${ }^{227}$ Id. (quoting Luis Moreno-Ocampo, Prosecutor of the ICC, Statement of the Prosecutor to the Diplomatic Corps

(Feb. 12, 2004), http://www.icc-cpi.int/library/organs/otp/LOM_20040212_En.pdf).

${ }^{228} I d$.
} 
March 2011, Kenya challenged the admissibility of the prosecutions against Kenyatta and Ruto under Article 19 of the Rome Statute on the ground that the government was investigating or prosecuting the case domestically. According to the government, "challeng[ing] Kenya's right to try its own citizens in the present circumstances would send out the wrong message to countries that are seeking to strengthen their national jurisdictions to fulfill their obligations under the Rome Statute . . .,229 This statement implies that the ICC has an obligation to build domestic capacity to facilitate the prosecution of international crimes. The statement also links the purported obligation to promote positive complementarity to respect for Kenyan sovereignty.

Kenyan officials also used the elision strategy in their political rhetoric against the Court. Specifically, the government alternately accused the ICC of failing to adequately equip Kenya to try the cases locally ${ }^{230}$ and failing to acknowledge the Kenyan people's desire to "move on."231

\section{Raising Complementarity Arguments Without a Basis in International Law}

The Kenyan government also raised complementarity arguments that had no basis in international law. For example, both Kenya and the AU repeatedly cited complementarity in support of their deferral requests to the UNSC. However, commentators generally agree that complementarity is not a legally valid basis for deferral, which instead turns on whether allowing a prosecution to continue threatens international peace and security. ${ }^{232}$

The references to complementarity in these requests in fact served a different objectiveframing the ICC as a political tribunal pitted against African sovereignty and African governments. By repeatedly invoking complementarity in multiple deferral requests, Kenya and the AU bolstered

\footnotetext{
${ }^{229}$ Prosecutor v. William Samoei Ruto, Henry Kiprono Kosgey, Joshua Arap Sang and Prosecutor v. Francis Kirimi Muthuara, Uhuru Muigai Kenyatta, Hohammad Hussein Ali, Application on the Behalf of the Government of the Republic of Kenya Pursuant to Article 19 of the ICC Statute, ICC-01/09-01/11 and ICC-01/09-02/11 I 10 (March 31, 2011) [hereinafter Kenyan Admissibility Challenge], http://www.icc-cpi.int/iccdocs/doc/doc1050005.pdf. ${ }^{230}$ Akwiri, supra note 134.

${ }^{231}$ Perceptions and Realities: Kenya and the International Criminal Court, supra note 135.

${ }^{232}$ Deferral \& Article 16, supra note 53. See also Hemi Mistry \& Deborah Verduzco, The UN Security Council and the International Criminal Court, CHATHAM House (Mar. 16, 2012), http://goo.gl/vP7Dcu.
} 
their argument that the ICC was implicitly disrespecting Africa by prosecuting its political leaders and judging its local and regional mechanisms inadequate. Cumulatively, the appeals to complementarity fueled the narrative that the ICC prosecutions represented the West's stubborn refusal to respect Kenya's sovereignty by facilitating domestic investigation and prosecution of the defendants. This narrative served bolstered the defendants' domestic popularity, increased public hostility to the ICC, and framed the cases against Kenyatta and Ruto as exemplars of a broader regional concern rather than a Kenya-specific problem.

\section{B. Regionalizing Backlash: Making the Prosecutions a Pan-African Concern}

The trials of Kenya's President and Deputy President for crimes committed during a Kenyan election was unquestionably a pressing national concern. Yet the government skillfully reframed the prosecutions as a pan-African problem by presenting them as the latest salvo in a long line of affronts to the sovereignty of all African nations. This regionalization strategy served two primary ends: it increased the political pressure on the ICC, and it deflected concerns about impunity by diverting focus from the defendants to a wider political context. The strategy is especially evidence in Kenya's efforts to lobby the UNSC for an Article 16 deferral and its encouraging an en masse withdrawal from the Rome Statute by African Union member states.

\section{Involving the African Union in Lobbying the Security Council for a Deferral}

As discussed in Section III(A), Kenyan officials recognized that their request for a UNSC deferral was unlikely succeed. The government used the failure of its request to regionalize concerns about the Kenyatta and Ruto prosecutions. The key to that strategy was drawing on the tensions surrounding the ICC prosecution of Sudan's President Omar al-Bashir. In that case, the UNSC did not respond to either of the African Union Peace and Security Council's two formal 
requests to defer the proceedings. The feelings of disrespect aroused by the UNSC's nonresponsiveness culminated in the AU's decision not to assist in al-Bashir's arrest. ${ }^{233}$

The Kenyan government capitalized on the momentum that the al-Bashir case generated by seeking AU backing before submitting its own deferral request. That choice allow Kenya to reframe the UNSC's denial of the request as the next step in a larger narrative of acrimonious Africa-ICC relations. When the UNSC did not respond to Kenya's first deferral request, the consequences were markedly pan-African. In May 2013, for example, the AU adopted its "Decision on Africa's Relationship with the International Criminal Court," which frames the prosecutions as an insult to African sovereignty. The Decision emphasizes "the need for international justice to be conducted in a transparent and fair manner, in order to avoid any perception of double standard" and notes that the prosecutions pose a threat to regional peace and security. And in October 2013, after its Extraordinary Summit, the AU issued a decision stating that President Kenyatta would not appear before the ICC until the UNSC considered Kenya's deferral request.

These efforts helped to push Kenya's second deferral request to a vote in the UNSC in November 2013. As discussed in Section III(A), the resolution seeking a deferral was not adopted. However, because the request was linked to the tensions of the al-Bashir case, its rejection reinforced Kenya's claim that the UNSC did not give sufficient credence to the views of African governments. The vote thus cemented the prosecutions' place in a narrative that, by virtue of the number of nations involved, posed a far graver threat to the ICC's legitimacy than a stand-off with Kenya alone. That broader narrative also deflected attention from the defendants' actions, stymying accusations of impunity.

\section{Raising En Masse Withdrawal Before the African Union}

\footnotetext{
${ }^{233}$ MATERU, supra note 46, at 248-53 (providing a detailed account of the effect of the cases on AU-ICC relations).
} 
As explained in Section III(B), the Kenyan Parliament adopted two motions to withdraw from the Rome Statute - the first in 2011 and the second in 2013. The latter motion helped to precipitate the African-wide withdrawal proposal that Kenya made brought before the AU during the October 2013 Extraordinary Summit. The motion thus further illustrates Kenya's efforts at regionalizing its conflict with the ICC.

The 2013 motion passed in Kenyan Parliament but President Kenyatta did not act upon the motion. ${ }^{234}$ Rather than taking the bold and unprecedented step of withdrawing from the Rome Statute unilaterally, Kenyatta sought AU support for a collective ICC withdrawal. The Parliament's adoption of the motion aided that effort in at least three ways: first, by demonstrating strong domestic support for the proposal; second, by signaling that politically powerful Kenya was committed to en masse withdrawal; and third, by cloaking the proposal in the mantle of democratic legitimacy. Had Kenyatta and Ruto approached the AU without the Parliament's backing, opponents might well have framed the proposal as an attempt to secure de facto impunity, making the AU less willing to champion Kenya's cause.

Excerpts of the speech that Kenyatta gave at the Extraordinary Summit, included in Section III(C), portray collective withdrawal as a necessary reaction to the ICC's "targeting" of Africa. The speech thus contributed to the overarching narrative that Kenya used to garner regional support for its opposition to the Court. Although AU member states ultimately decided against en masse withdrawal, the fact that the largest regional block of Rome Statute signatories gave the proposal serious consideration sent a strong political message to the ICC.

C. Coupling Condemnation with Cooperation to Diffuse Accusations of Impunity

Kenyatta and Ruto's concerted campaign against the ICC was, somewhat paradoxically, also marked by periodic public commitments to cooperate with the proceedings in the Hague. These shows

\footnotetext{
${ }^{234}$ This also reflects another pattern: pairing backlash with shows of cooperation. That point is discussed below in subsection $\mathrm{C}$.
} 
of cooperation served several purposes. First, they enhanced the defendants' popularity in Kenya, ultimately helping to turn public opinion against the ICC. Second, the supposed willingness to cooperate likely made the government's backlash more palatable to other AU member states, generating regional support that enabled Kenya to place more political pressure on the ICC than it could have generated on its own.

\section{The 2013 Presidential Elections}

The approach the defendants took to during the 2013 election campaign illustrates the effectiveness of combining cooperation and backlash. Although the ICC prosecutions initially enjoyed widespread support from the Kenyan public, that support did not survive the defendants' 2013 election. During the 2007 presidential elections that precipitated the post-election violence Kenyatta and Ruto were political opponents. After the Pre-Trial Chamber confirmed the charges against them, the defendants formed the Jubilee Coalition that united different ethnic groups.

In light of the trials' initial popularity, the defendants shrewdly avoided running an exclusively anti-ICC campaign. Instead, they promised to cooperate with the prosecutions. In assuring the public of their cooperation, the pair framed the indictments as personal matters that would not interfere with their ability to govern. They also avoided the appearance of shirking accountability for the violence that followed the 2007 elections. The strategy appeared to succeed, in that public support for the two candidates increased even as ICC prosecutions remained popular in the run-up to the 2013 presidential elections.

At the same time, Kenyatta and Ruto villainized the ICC prosecutions as a threat to the sovereignty of Kenya and of Africa in general. They also portrayed the prosecutions as an attempt by the West to favor its preferred candidate, Odinga, and to dissuade the Kenyan people from voting for Kenyatta. At first, the defendants focused more on cooperation than on criticizing the ICC. But as the 
pair gained in popularity, their rhetoric against the Court increased as the public became more open to the anti-ICC narrative they offered up.

After the election and their assumption of the Presidency and Deputy Presidency respectively, Kenyatta and Ruto increasingly framed their trials as disrespectful of Kenya's sovereignty. For example, in a statement made after his election Kenyatta warned: "I speak not as an accused person, but as the President of the sovereign Republic of Kenya . . . "235 Polling reflects this strategy's effectiveness, revealing the defendants' election as one cause of the decline in public support for the ICC prosecutions. Yet both officials continued to emphasize their individual cooperation with the ICC process even after their elections - a position that was consistent with their campaign promises and likely kept accusations of impunity at bay.

\section{Kenyatta's Appearance in the Hague in October 2014}

Perhaps the best illustration of the defendants' savvy in making shows of cooperation while undermining the Court is Kenyatta's dexterous handling of his appearance at a status conference in the Hague in October 2014. By agreeing to appear in person, Kenyatta made a show of cooperationone that he drew attention to in his April 2014 presidential address. ${ }^{236}$ But he also undermined the trials by temporarily stepping down as the President of Kenya. Kenyatta framed this decision as necessary to "avoid putting the sovereignty of more than forty million Kenyans on trial," thereby implying that the prosecution of the country's sitting President evidenced the ICC"s disrespect for Kenyan sovereignty. ${ }^{237}$ Kenyatta's decision was widely supported $^{238}$ and particularly dramatic given

\footnotetext{
${ }^{235}$ Olive Burrows, Uhuru: Ruto and I cannot be at the ICC Concurrently, CAPITAL NEWS (Sept. 8, 2013), http://www.capitalfm.co.ke/news/2013/09/uhuru-ruto-and-i-cannot-be-at-the-icc-concurrently/.

${ }^{236}$ Kenya: Ruto the Acting President as I Attend ICC Case, supra note 216.

${ }^{237}$ Id.

${ }^{238}$ African Union, Twenty-Fourth Ordinary Session, Jan. 30-31, 2015, Decision on the Progress Report of the Commission on the Implementation of the Assembly Decisions on the International Criminal Court, in Decisions, Declarations, and Resolutions, ๆ 5, Assembly/AU/Dec. 546-568 (XXIV), http://goo.gl/rMXkRK.
} 
that the constitutional provision he invoked to temporarily transfer presidential power to Ruto had never before been used.

\section{Conclusion}

The efforts by the Government of Kenya to oppose the ICC prosecutions of President Kenyatta and Deputy President Ruto were many and varied. Although previous studies have viewed these efforts as discrete and unrelated, a closer examination reveals that the government's actions were part of an integrated backlash strategy linked by several overarching themes.

First, Kenyan officials capitalized on ambiguities in the complementarity doctrine to recast the ICC trials as an affront to the country's sovereignty. The government also framed the prosecutions as a pan-African concern - the latest in a long line of post-colonial Western impositions on African nations. Third, Kenya publicly emphasized its cooperation with the ICC while simultaneously acting in ways that undercut the prosecutions. All three aspects of the backlash campaign included maneuvers within the framework of the ICC legal regime - such pre-trial motions and requests for the UN Security Council to defer the prosecutions - as well as actions taken outside of that framework - including attempts to delegitimize the Court and proposals for a region-wide withdrawal from the Rome Statute.

The success of Kenya's integrated backlash strategy - as indicated in the dismissal of the prosecutions, the reduction in public and government support for the ICC across Africa - offer a troubling roadmap for other states to oppose prosecutions before the ICC as well as ad hoc or hybrid criminal tribunals. By manipulating ambiguous doctrines, challenging the legal basis for prosecutions using geopolitical arguments that appeal to neighboring countries, and by tacitly refusing to cooperate with ongoing proceedings while publicly (but disingenuously) professing to recognize the authority

of the court, its judges and staff, opponents of international justice can obfuscate and delay proceedings until the prosecution is forced to make a sua sponte decision to dismiss the indictments. 
Whether similar backlash strategies will be effective for other international courts and tribunals is less certain. Criminal trials require the presence of the accused and the proceedings included procedural safeguards and due process protections that give strategic leverage not only to defendants and their council also but to state officials who support them. The same rules do not apply to international courts that adjudicate state responsibility for violating human rights, trade and investment rules, environmental protection agreements, and other public international law obligations. If a court has jurisdiction over a state by virtue of its membership in a treaty regime, the judges on the tribunal will review the merits of the case - and, where appropriate, declare violations of the law and award appropriate remedies - regardless of whether the government and its officials participate in the proceedings. With a favorable judgment in hand, legal advocates and their clients can deploy a range of strategies to pressure the state to respond. They can seek to enforce the ruling domestically, publicize the judges' reasoning and findings to bolster the legitimacy of their demands, and use the ruling to embarrass political leaders into adopting their preferred legal and policy reforms. 
Authors: Laurence R. Helfer and Anne E. Showalter

Title: Opposing International Justice: Kenya's Integrated Backlash Strategy Against the ICC iCourts Working Paper, No. 83, 2017

Publication date: 03/January/2017

URL: http://jura.ku.dk/icourts/working-papers/

(C) Author

iCourts Working Paper Series

ISSN: 2246-4891

Laurence R. Helfer, Harry R. Chadwick, Sr. Professor of Law, Duke University School of Law, USA, and Permanent Visiting Professor, Centre of Excellence for International Courts (iCourts), University of Copenhagen, Denmark.

E-mail: helfer@law.duke.edu

Anne E. Showalter, J.D. / LLM in International and Comparative Law, Duke University School of Law, USA.

E-mail: aes75@duke.edu

The iCourts Online Working Paper Series publishes pre-print manuscripts on international courts, their role in a globalising legal order, and their impact on politics and society and takes an explicit interdisciplinary perspective.

Papers are available at http://jura.ku.dk/icourts/

iCourts

- The Danish National Research Foundation's Centre of Excellence for International Courts

The Faculty of Law

University of Copenhagen

Studiestraede 6

DK-1455 Copenhagen $\mathrm{K}$

E-mail: icourts@jur.ku.dk

Tel. +4535322626 